\title{
The arabidopsis cyclic nucleotide interactome
}

\author{
Lara Donaldson ${ }^{1,2^{*}}$, Stuart Meier ${ }^{1}$ and Christoph Gehring ${ }^{1}$
}

\begin{abstract}
Background: Cyclic nucleotides have been shown to play important signaling roles in many physiological processes in plants including photosynthesis and defence. Despite this, little is known about cyclic nucleotidedependent signaling mechanisms in plants since the downstream target proteins remain unknown. This is largely due to the fact that bioinformatics searches fail to identify plant homologs of protein kinases and phosphodiesterases that are the main targets of cyclic nucleotides in animals.

Methods: An affinity purification technique was used to identify cyclic nucleotide binding proteins in Arabidopsis thaliana. The identified proteins were subjected to a computational analysis that included a sequence, transcriptional co-expression and functional annotation analysis in order to assess their potential role in plant cyclic nucleotide signaling.

Results: A total of twelve cyclic nucleotide binding proteins were identified experimentally including key enzymes in the Calvin cycle and photorespiration pathway. Importantly, eight of the twelve proteins were shown to contain putative cyclic nucleotide binding domains. Moreover, the identified proteins are post-translationally modified by nitric oxide, transcriptionally co-expressed and annotated to function in hydrogen peroxide signaling and the defence response. The activity of one of these proteins, GLYGOLATE OXIDASE 1, a photorespiratory enzyme that produces hydrogen peroxide in response to Pseudomonas, was shown to be repressed by a combination of cGMP and nitric oxide treatment.
\end{abstract}

Conclusions: We propose that the identified proteins function together as points of cross-talk between cyclic nucleotide, nitric oxide and reactive oxygen species signaling during the defence response.

Keywords: CAMP, cGMP, Cross-talk, Cyclic nucleotide, Defence response, $\mathrm{H}_{2} \mathrm{O}_{2}$, Hypersensitive response, Nitric oxide, Reactive oxygen species, Second messenger

\section{Background}

The sessile nature of plants demands that they are able to detect and rapidly adapt to changes in their environment. Second messengers are critical to this adaptation as they relay extracellular environmental and developmental signals into intracellular information that is decoded into appropriate physiological responses. A suite of small, transient molecules function as plant second messengers including calcium, cyclic nucleotides (CNs), phospholipids, cyclic

\footnotetext{
*Correspondence: lara.donaldson@uct.ac.za

${ }^{1}$ Biological and Environmental Sciences and Engineering Division, King

Abdullah University of Science and Technology, Thuwal 23955-6900, Saudi Arabia

${ }^{2}$ Department of Molecular and Cell Biology, University of Cape Town, Private Bag $\times 3$, Rondebosch 7701, South Africa
}

ADP ribose, reactive oxygen species (ROS), nitric oxide (NO) and changes in cytosolic $\mathrm{pH}$ [1-3].

The CNs, adenosine 3', 5'-cyclic monophosphate (cAMP) and guanosine 3', 5'-cyclic monophosphate (cGMP) are well characterized and conserved second messengers that have important functional roles in prokaryotes and eukaryotes [4]. In animals, CNs are synthesised in response to extracellular signals that activate intracellular nucleotidyl cyclases (NCs) which catalyse the synthesis of cAMP and cGMP from their respective nucleotide triphosphate substrates, adenosine triphosphate (ATP) and guanosine triphosphate (GTP). These $\mathrm{CNs}$ bind to and activate $\mathrm{CN}$ binding proteins (CNBPs) including cAMP- and cGMP-dependent protein kinases (PKA and PKG) which are considered to be the main 
effectors of $\mathrm{CN}$ signaling in animals [5]. In addition, $\mathrm{CNs}$ bind to $\mathrm{CN}$-gated and hyperpolarization-activated $\mathrm{CN}$-modulated channels (CNGCs and $\mathrm{HCNs}$ ) which have specialized roles in sensory perception and control of rhythmicity, respectively [6]. Finally, intracellular $\mathrm{CN}$ concentrations are tightly regulated by phosphodiesterases (PDEs) that bind and metabolize cAMP and cGMP to inactive nucleotide monophosphates [4].

Sequence and structural analysis of bacterial and animal CNBPs indicate that $\mathrm{CNs}$ bind to conserved $\mathrm{CN}$ binding domains (CNBDs). Although different types of CNBPs have been discovered across kingdoms, only two evolutionary distinct CNBDs have been characterized: 1) the CNB domain, present in PKA, PKG, CNGCs, HCNs and the Escherichia coli transcription factor, catabolite activator protein (CAP) and 2) the GAF domain, so called because it is found in cGMP binding PDEs, Anabaena adenylyl cyclase and E. coli FhlA [7].

For decades the presence of CNs in plants was debated [4] but it was not until mass spectrometry (MS) methods were employed that the existence of CNs in plants was proven unequivocally [8]. Since then CNs have been implicated in phytochrome signaling during chloroplast development [9], stomatal movements [10, 11] and responses to: plant hormones [12, 13], ozone [14], NO [12, 15, 16] and abiotic and biotic stresses $[17,18]$. Despite this, $\mathrm{CN}$ signal transduction in plants is poorly understood because the upstream and downstream components of the pathway remain elusive.

Recently, progress has been made toward the discovery of upstream NCs in plants. Alignment of the catalytic domains of NCs across kingdoms has identified conserved, functionally important amino acids that have been used to construct rational search motifs to query plant genomes and identify candidate NCs [19-21]. To date six putative plant NCs, identified in this way, have been recombinantly expressed and shown to produce CNs in vitro [19, 22-26]. Additionally, overexpression of one of the NC candidates, the phytosulfokine receptor, in protoplasts results in a 20 fold increase in cGMP levels demonstrating that this receptor has $\mathrm{NC}$ activity in vivo [24].

Less is known about downstream $\mathrm{CN}$ signaling mechanisms in plants. While $\mathrm{CN}$ binding activity and $\mathrm{CN}$ modulated protein activity has been demonstrated in oat and morning glory, the corresponding CNBPs have not been identified [27, 28]. Bioinformatics searches for CNBDs in plants, have failed to identify homologs of animal PKA, PKG or PDEs [7]. Plants do however possess an expanded family of CNGCs which suggests that these are the main targets of $\mathrm{CN}$ signaling in plants [29]. Other plant proteins that harbour the canonical CNB signature include a family of shaker-type $\mathrm{K}^{+}$channels, acetyl CoA thioesterases, a protein phosphatase $2 \mathrm{C}(\mathrm{PP} 2 \mathrm{C})$ and the $\mathrm{Na}^{+} / \mathrm{H}^{+}$antiporter,
SALT OVERLY SENSITIVE 1 (SOS1) [7]. There is experimental evidence to support $\mathrm{CN}$-mediated regulation of CNGCs and $\mathrm{K}^{+}$channels [30,31], however the function of the CNB site in acetyl CoA thioesterases, PP2C and SOS1 has not yet been explored. On the other hand, GAF domains have been identified in plant phytochromes and ethylene receptors [7]. The fact that CNs play a role in phytochrome signaling suggests these GAF domains are functional [9]. Similarly, ethylene receptors resemble bacterial histidine kinases that contain functional GAF domains [32] and there is some evidence that cGMP plays a role in ethylene signaling [14]. While CNB and GAF domains have been identified in a number of plant proteins, there is little direct evidence that CNs bind and regulate the activity of these proteins.

Plant CNGCs have been studied extensively and shown to facilitate $\mathrm{CN}$ activated $\mathrm{Na}^{+}, \mathrm{K}^{+}$and $\mathrm{Ca}^{2+}$ currents [33-38]. Furthermore, $c n g c$ mutants have revealed functional roles for CNGCs in plant defence against pathogens and particularly the hypersensitive response [39-42], leaf senescence [43], floral transition [44, 45], germination [46], salt tolerance [47, 48], heavy metal tolerance [49], thermotolerance [37, 50], starch accumulation and growth [51, 52], gravitropism [53], polarized tip growth of pollen [54], pollen tube guidance [55], stress tolerance in pollen reproductive development [56] and male reproductive fertility [57]. Additionally, CNGCs have been localized to guard cells suggesting that they play a role in stomatal movements [38]. While CNGCs certainly function in a wide array of physiological processes in plants, the question of whether these are the only effectors of plant $\mathrm{CN}$ signalling remains to be answered.

Recent studies have demonstrated that exogenous $\mathrm{CN}$ treatment induces changes in the plant transcriptome $[58,59]$ and phosphoproteome [60] supporting that CNs modulate downstream targets in plants, similar to prokaryotes and other eukaryotes. However, the apparent lack of plant $\mathrm{CN}$-dependent protein kinases and transcription factors suggests that the mechanism by which $\mathrm{CNs}$ mediate their effects in plants differs from that in prokaryotes and other eukaryotes. Clearly, the identification of downstream CNBPs is essential to advance our understanding of $\mathrm{CN}$ signaling pathways in plants. In the past decade, experimental strategies using synthetic $\mathrm{CNs}$ to affinity purify CNBPs have been developed to gain insight into $\mathrm{CN}$ signaling in animals. These strategies have been successfully used to isolate known CNBPs (PKA, PKG, PDE, CNGC, HCN and CAP) and identify novel PKA-associated scaffold proteins [61, 62]. Here, we have adapted and applied this methodology to identify CNBPs in Arabidopsis thaliana. Twelve CNBPs have been successfully identified and their potential role in plant $\mathrm{CN}$ signaling investigated. 


\section{Methods}

Plant material

Arabidopsis Col-0 was grown in a peat/vermiculite mixture at $22{ }^{\circ} \mathrm{C}$ and $55 \%$ humidity under a $16 \mathrm{~h}$ light $(100 \mu \mathrm{M}$ photons $\left.\mathrm{m}^{-2} \mathrm{~s}^{-1}\right) 8 \mathrm{~h}$ dark cycle. After four weeks, leaf tissue was harvested. Arabidopsis Col-0 callus cell cultures were grown shaking at $23{ }^{\circ} \mathrm{C}$ under continuous light in Gamborg's B5 media with vitamins, $2 \%(w / v)$ sucrose, $0.05 \%(w / v)$ 4-morpholineethanesulfonic acid, $0.5 \mathrm{mg} \mathrm{l}^{-1}$ 2,4-dichlorophenoxyacetic acid, $50 \mu \mathrm{g} \mathrm{l^{-1 }}$ kinetin at $\mathrm{pH} 5.7$. Cells were sub-cultured weekly, grown for nine days then collected by filtration.

\section{Chemicals}

Synthetic CN baits: 2-(6-aminohexylamino) cAMP agarose (2-AHA-cAMP-agarose); 8-(2-aminoethylamino) cAMP agarose (8-AEA-cAMP-agarose); 2-(6-[Biotinyl] aminohexylamino) cAMP (2-[Biotin]-AHA-cAMP); N2-(6aminohexyl) cGMP agarose (2-AH-cGMP-agarose); 8-(2aminoethylthio) cGMP agarose (8-AET-cGMP-agarose); N2-(6-[Biotinyl] aminohexyl) cGMP (2-[Biotin]-AHcGMP) and the ethanolamine agarose (EtOH-NH-agarose) negative control were purchased from BioLog Life Science Institute (Bremen, Germany). Dynabeads ${ }^{\oplus}$ MyOne $^{\text {ra }}$ Streptavidin $\mathrm{C} 1$ and Dynabeads ${ }^{\odot}$ Co-Immunoprecipitation kit were purchased from Invitrogen/Dynal (Oslo, Norway). THE $^{\text {тм }}$ cAMP and $\mathrm{THE}^{\mathrm{TM}}$ cGMP antibodies were purchased from GenScript (Piscataway, NJ).

\section{Affinity purification overview}

Leaf and callus proteins were incubated with four different baits for either cAMP or cGMP. The cAMP baits were: 2-AHA-cAMP-agarose; 8-AEA-cAMP-agarose; 2[Biotin]-AHA-cAMP and cAMP antibodies while the cGMP baits were: 2-AH-cGMP-agarose; 8-AET-cGMPagarose; 2-[Biotin]-AH-cGMP and cGMP antibodies (Additional file 1). The synthetic $\mathrm{CN}$ baits differed in their linkers (hexyl or ethyl), linkage positions to the nucleotide moiety (2 or 8 ) and scaffolds (biotin or agarose) and were used to eliminate non-specific binding associated with using a single bait. The antibody baits pulled down proteins bound to endogenous $\mathrm{CNs}$ and were used to confirm findings with the synthetic CNs.

\section{Protein extraction}

Approximately $5 \mathrm{~g}$ leaf or callus tissue was ground to a fine powder in liquid nitrogen and dissolved in $10 \mathrm{ml}$ assay buffer: $50 \mathrm{mM}$ Tris- $\mathrm{HCl} \mathrm{pH}$ 7.4, $0.25 \mathrm{M}$ sucrose, $1 \mathrm{mM}$ ethylenediaminetetraacetic acid, $0.1 \mathrm{mM} \mathrm{MgSO}_{4} .7 \mathrm{H}_{2} \mathrm{O}$, $10 \mathrm{mM} \mathrm{KCl}, 5 \mathrm{mM}$ ascorbic acid, $1 \mathrm{mM}$ phenylmethanesulfonyl fluoride, $1 \times$ protease inhibitor cocktail (Sigma P9599). Insoluble $0.5 \%(w / v)$ poly (vinylpolypyrrolidone) was added to remove polyphenols. The protein extracts were centrifuged at $12000 \times g$ for $20 \mathrm{~min}$ at $4{ }^{\circ} \mathrm{C}$ to obtain a clarified supernatant. The protein concentration of the supernatant was determined, as described previously [63] to be approximately $1 \mathrm{mg} \mathrm{ml}^{-1}$. The leaf or callus protein extracts were divided into nine $1 \mathrm{ml}$ aliquots and affinity purified using the four different cAMP baits, four cGMP baits and negative control.

\section{Affinity purification Agarose baits}

In pull-down experiments with agarose baits, $200 \mu \mathrm{l}$ beads were used, corresponding to approximately $1 \mathrm{nmol}$ cAMP or cGMP. The agarose beads were equilibrated with $1 \mathrm{ml}$ assay buffer in an Eppendorf tube for $2 \mathrm{~h}$ at $4{ }^{\circ} \mathrm{C}$ with gentle agitation on a rotator at $40 \mathrm{rpm}$. The beads were collected by centrifugation at $100 \times g$ for $30 \mathrm{~s}$ and the assay buffer removed. Approximately $1 \mathrm{mg}$ leaf or callus proteins ( $1 \mathrm{ml}$ protein extract) were incubated with the pre-equilibrated agarose beads for $4 \mathrm{~h}$ at $4{ }^{\circ} \mathrm{C}$, with gentle agitation. The protein-bound beads were collected by centrifugation and affinity purified proteins processed as described below.

\section{Biotin baits}

In pull-down experiments with biotin baits, $1 \mathrm{mg}$ streptadvin-linked dynabeads (capable of binding 2.5 nmol biotin) were used. These were equilibrated with $1 \mathrm{ml}$ assay buffer in an Eppendorf tube for $2 \mathrm{~h}$ at $4{ }^{\circ} \mathrm{C}$ with gentle agitation on a rotator at $40 \mathrm{rpm}$, then collected with a Dynamag magnet and the assay buffer removed. Concurrently, approximately $1 \mathrm{mg}$ leaf or callus proteins were pre-incubated with 1 nmol 2[Biotin]-AHA-cAMP or 2-[Biotin]-AH-cGMP for $1 \mathrm{~h}$ at $4{ }^{\circ} \mathrm{C}$ with gentle agitation. The biotin-bound proteins were then incubated with the pre-equilibrated streptavidin-linked dynabeads for $4 \mathrm{~h}$ at $4{ }^{\circ} \mathrm{C}$, with gentle agitation. The protein-bound dynabeads were collected with a Dynamag and affinity purified proteins processed as described below.

\section{Antibody baits}

Antibody-coupled dynabeads were generated by covalently coupling $50 \mu \mathrm{g}$ cAMP or cGMP antibody to $8 \mathrm{mg}$ Dynabeads $^{\oplus}$ M-270 Epoxy using the Dynabeads ${ }^{\oplus}$ CoImmunoprecipitation kit, according to the manufacturer's instructions. In each immunoaffinity purification experiment $4 \mathrm{mg}$ antibody-coupled dynabeads were used. The antibody-coupled dynabeads were equilibrated with $1 \mathrm{ml}$ assay buffer for $2 \mathrm{~h}$ at $4{ }^{\circ} \mathrm{C}$ with gentle agitation on a rotator at $40 \mathrm{rpm}$ then collected with a Dynamag and the assay buffer removed. Approximately $1 \mathrm{mg}$ leaf or callus proteins were incubated with the pre-equilibrated antibody-coupled dynabeads for $4 \mathrm{~h}$ at $4{ }^{\circ} \mathrm{C}$, with gentle agitation. The protein-bound 
dynabeads were collected with a Dynamag, and affinity purified proteins processed as below.

\section{Affinity purified protein processing}

The protein-bound agarose or dynabeads were washed six times with $1 \mathrm{ml}$ assay buffer then subjected to a sequential elution series of increasing stringency and the elution and bead fractions collected, as described previously [63]. The protein concentration of the elution fractions was low, so proteins were precipitated, as described previously [63]. The elution and bead fractions were separated by sodium dodecyl sulphate-polyacrylamide gel electrophoresis and fractionated proteins processed by in-gel tryptic digest, as described previously [63].

\section{Mass spectrometry}

Dried peptides were reconstituted in $12 \mu \mathrm{l} 0.1 \%(v / v)$ formic acid (FA), $5 \%(v / v)$ acetonitrile $(\mathrm{ACN})$ and analysed using a Q-TRAP 5500 mass spectrometer (Applied Biosystems, Foster City, CA) connected to a Proxeon nano-liquid chromatography system. For each sample, $5 \mu \mathrm{l}$ was loaded onto a reverse phase C18 trap column, washed, then eluted at $500 \mathrm{nl} \mathrm{min}{ }^{-1}$ using a $3 \mu \mathrm{M} 200^{\circ} \mathrm{A}$ Magic C18AQ online analytical column connected to a captive-spray source (Michrom, Auburn, CA). Peptides were eluted in a linear gradient of 5-40\% ACN, $0.1 \%$ FA for $25 \mathrm{~min}$; a linear gradient of $40-80 \% \mathrm{ACN}, 0.1 \%$ FA for 5 min then an isocratic gradient of $80 \% \mathrm{ACN}$, $0.1 \% \mathrm{FA}$ for $15 \mathrm{~min}$. Eluted peptides were analysed online by electrospray ionization-MS using Analyst (version 1.5.2) to select MS scans of $\mathrm{m} / \mathrm{z}$ 300-1000. Each MS scan went through four rounds of MS/MS with dynamic exclusion. The MS/MS data were compared to the Arabidopsis_TAIR10 protein database using Mascot (version 2.3) and results compiled with Scaffold (version 3.6). Positive matches had a peptide identification probability of $95 \%$ and corresponding proteins were represented by at least two peptides with a protein identification probability of $99 \%$.

\section{Alignment of candidate proteins with cyclic nucleotide binding domains}

Representative CNB domains were downloaded from Interpro (IPR000595) for sequence analysis including Homo sapiens: PKAI [EMBL:P10644]; PKGI [EMBL:Q13976]; HCN1 [EMBL:O60741]; CNGCß1 [EMBL:P29973]; CNGC $\alpha 1$ [EMBL:Q14028]; exchange protein activated by cAMP (EPAC) 1 [EMBL:O95398] and EPAC2 [EMBL:Q8WZA2] and E. coli: CAP [EMBL:P0ACJ8]. GAF domains were retrieved by BLAST searches including $H$. sapiens: PDE2 [EMBL:O00408] and PDE5 [EMBL:O76074]; Anabaena sp. PCC 7120 adenylyl cyclases: CYAB [EMBL:P94181] and CYAC [EMBL:P94183] and E. coli: FhlA [EMBL:P19323].
Alignments were performed with the Molecular Evolutionary Genetic Analysis (MEGA) 5 program [64].

\section{Computational analysis of cyclic nucleotide binding proteins \\ Transcriptional co-expression analysis}

A transcriptional co-expression analysis was conducted using the Expression Angler tool in Botany Array Resource [65] to determine the level of co-expression shared by each of the candidate CNBPs. The analysis was performed against the NASCArrays 392 microarray dataset, using each of the 12 candidate CNBPs as the driver gene and extracting correlated genes with $r$ values between 0.7-1.0. An expression correlation matrix was constructed using the correlated gene list for each CNBP driver gene and extracting $r$-values for the other candidate CNBPs (Table 3).

\section{Differential expression analysis}

Genevestigator [66] was used to identify experimental conditions that induced the differential expression of the ten expression correlated CNBP candidates from Table 3. Normalised microarray experiments were downloaded from Gene Expression Omnibus [67]: light/dark (GSE9728), Pseudomonas syringae pv maculicola (Psm)/ mock (GSE18978), Pseudomonas syringae pv tomato (Pst) DC3000/mock and Pst DC3000 hrpA/mock (GSE5520). The nitrate starved/replete experiment was downloaded from [68]. Data was processed in excel to generate $\log _{2}$ fold change ratios and heat maps were constructed with the MultiExperiment Viewer tool in TMev [69].

\section{Glycolate oxidase assay}

Leaves of four week old Arabidopsis were pressure infiltrated with either $10 \mathrm{mM} \mathrm{MgCl}_{2}$ (control) or $10^{6}$ colony forming units (cfu) $\mathrm{ml}^{-1}$ Pst DC3000 or Pst DC3000 AvrRpm1. For cGMP and NO treatments, $50 \mu \mathrm{M} 8-\mathrm{Br}$ cGMP and/or $50 \mu \mathrm{M}$ diethylamine NONOate were coinfiltrated with $\mathrm{MgCl}_{2}$ or Pst. GOX activity was measured in Pst infected and control plants. Three leaves from each plant were collected $24 \mathrm{~h}$ post infection since GOX activity has been shown to contribute to Pst-induced $\mathrm{H}_{2} \mathrm{O}_{2}$ production within this time frame. Leaves were ground to a fine powder in liquid nitrogen then added to $500 \mu \mathrm{l}$ protein extraction buffer and processed as described previously [70]. Briefly, GOX activity in the protein extract catalyses the conversion of the sodium glycolate substrate to glyoxylate, releasing $\mathrm{H}_{2} \mathrm{O}_{2}$. The $\mathrm{H}_{2} \mathrm{O}_{2}$ reacts with $\mathrm{O}$-dianisidine in the presence of horseradish peroxidase to produce the coloured O-dianisidine radical which can be quantified spectrophotometrically at $440 \mathrm{~nm}$ [71]. 


\section{Results \\ Identification of candidate cyclic nucleotide binding proteins}

Arabidopsis leaf and callus protein extracts were incubated with four different baits for cAMP or cGMP and the interacting proteins were purified as described previously [63]. A range of baits was used to ensure that specific interactions between proteins and CNs were identified (see Methods) and a sequential elution series was used to displace low affinity binding proteins [61]. A total of 119 proteins were identified from leaf and callus protein extracts, after subtracting proteins that were pulled down with the negative control bait (Additional file 2). The list was filtered to identify the best candidate CNBPs. Briefly, only proteins that were identified with more than one type of bait and that survived the stringent elution process were retained, producing a final list of 13 candidate CNBPs (Table 1; corresponding peptides in Additional file 3). The candidate CNBPs bound tightly to the baits and were not displaced during the sequential elution process. None of the candidate CNBPs bound selectively to the cAMP or cGMP baits. Of the 13 proteins identified, 11 were specific to leaf, one was found in both leaf and callus and one was unique to callus. Notably, 12 of the 13 CNBP candidates were purified with $\mathrm{CN}$-specific antibodies supporting that these proteins bind endogenous CNs. The 13 candidate CNBPs identified were subsequently analysed for potential roles in $\mathrm{CN}$ signaling.

\section{Candidate CNBPs have putative cyclic nucleotide binding domains}

The candidate CNBPs were queried against the UniProt and Interpro databases [72, 73] to determine whether they contain binding domains or binding sites for cyclic or similar nucleotides. During this analysis it was noted that peptides mapping to SECRETION ASSOCIATED RAS 1B do not retrieve a single protein but rather a family of similar proteins. As it is impossible to determine which of these bound the bait, all were excluded from further analysis. The search revealed that none of the candidate CNBPs are annotated to bind CNs. However, several candidate CNBPs are annotated to bind adenine and guanine containing nucleotides (Table 2). The ATP binding proteins include EUKARYOTIC TRANSLATION INITIATION FACTOR 4A1 (EIF4A1), PHOSPHOGLYCERATE KINASE 1 (PGK1) and CASEINOLYTIC PROTEASE C HOMOLOG 1 (CLPC1). The NAD/NADP binding proteins include GLYCERALDEHYDE-3-PHOSPHATE DEHYDROGENASE B SUBUNIT (GAPB), CHLOROPLAST STEM-LOOP BINDING PROTEIN OF $41 \mathrm{kDa}$ (CSP41B) and PROTOCHLOROPHYLLIDE OXIDOREDUCTASE B (PORB). Finally, RAS-
RELATED IN BRAIN GTPase HOMOLOG E1b (RABE1b) binds GTP (Table 2). The remaining candidate CNBPs have no known affinity for other nucleotides including GLYCOLATE OXIDASE (GOX1), TRANSKETOLASE (TKL), SERINE HYDROXYMETHYLTRANSFERASE 1 (SHMT1), ATP SYNTHASE DELTA-SUBUNIT (ATPD) and CARBONIC ANHYDRASE 1 (CA1).

To investigate whether the candidate CNBPs contain potential CNBDs, their sequences were aligned with known CNBDs. To achieve this, CNB domains were extracted from representative organisms across kingdoms including human, mouse, chicken, frog, fish, fly, worm, slime mould, protozoa, yeast, bacteria, cyanobacteria, algae, moss, Arabidopsis and rice. Since the GAF domain is less constrained than the CNB domain, only published GAF domains from human, yeast, bacteria, cyanobacteria, Arabidopsis and sorghum [74-78] were considered. More than $200 \mathrm{CNB}$ sequences and $50 \mathrm{GAF}$ sequences were aligned with the identified Arabidopsis candidate CNBPs (Additional files 3 and 4). The alignment results were simplified to show only the candidate CNBPs that did align with select CNB and GAF domains from well-known CNBPs (Figs. 1 and 2). Eight of the candidate CNBPs have sequences that resemble known CNBDs (CNBD-like sequences) with several candidates aligning with both $\mathrm{CNB}$ and GAF domains (Table 2). Specifically, CNB-like sequences were identified in PGK1, GAPB, TKL, SHMT1 and PORB while GAF-like sequences were identified in EIF4A1, PGK1, GAPB, TKL, SHMT1, GOX1 and CA1. Only RABE1b, CLPC1, ATPD and CSP41B did not align with either CNBD. Thus, eight of the 12 candidate CNBPs contain CNBD-like sequences, validating the experimental approach.

\section{Candidate CNBPs are modified by nitric oxide}

An investigation of The Arabidopsis Information Resource (TAIR) database revealed that a number of the candidate CNBPs are annotated to be post-translationally modified (PTM) by NO. Further investigation of the literature revealed that ten of the candidate CNBPs have been experimentally determined to be modified by NO with several being modified by both S-nitrosylation and Y-nitration [79-82] (Table 2). Specifically, EIF4A1, PGK1, GAPB, RABE1b, TKL, CSP41B and CA1 are modified by Snitrosylation while GAPB, RABE1b, TKL, SHMT1, GOX1, CSP41B, PORB and CA1 are modified by Y-nitration. Of the ten NO-modified candidate CNBPs, seven also contain CNBD-like sequences. For two of the ten NO-modified candidate CNBPs, TKL and CA1, the PTM site has been determined [81, 83]. In TKL, the modified tyrosine (Y337) lies within the putative $\mathrm{CNB}$ domain (Table 2) and this tyrosine is conserved in $\mathrm{CNB}$ domains of $E$. coli CAP and type II PKAs (Fig. 1, Additional file 4). Similarly, in CA1 the nitrosylated C280 lies within the GAF domain and a 
Table 1 Arabidopsis cyclic nucleotide binding protein candidates

\begin{tabular}{|c|c|c|c|c|c|c|c|c|c|c|c|c|c|c|c|c|c|}
\hline \multirow[b]{2}{*}{ Accession } & \multirow[b]{2}{*}{ Description } & \multicolumn{4}{|c|}{ LEAF CAMP } & \multicolumn{4}{|c|}{ LEAF CGMP } & \multicolumn{4}{|c|}{ CALLUS CAMP } & \multicolumn{4}{|c|}{ CALLUS CGMP } \\
\hline & & $\begin{array}{l}\text { 2-AHA- } \\
\text { CAMP- } \\
\text { agarose }\end{array}$ & $\begin{array}{l}\text { 8-AEA- } \\
\text { CAMP- } \\
\text { agarose }\end{array}$ & $\begin{array}{l}\text { 2-[Biotin]- } \\
\text { AHA- } \\
\text { CAMP }\end{array}$ & $\begin{array}{l}\text { CAMP } \\
\text { antibody }\end{array}$ & $\begin{array}{l}\text { 2-AH- } \\
\text { cGMP- } \\
\text { agarose }\end{array}$ & $\begin{array}{l}\text { 8-AET- } \\
\text { CGMP- } \\
\text { agarose }\end{array}$ & $\begin{array}{l}\text { 2-[Biotin]- } \\
\text { AH-cGMP }\end{array}$ & $\begin{array}{l}\text { cGMP } \\
\text { antibody }\end{array}$ & $\begin{array}{l}\text { 2-AHA- } \\
\text { CAMP- } \\
\text { agarose }\end{array}$ & $\begin{array}{l}\text { 8-AEA- } \\
\text { CAMP- } \\
\text { agarose }\end{array}$ & $\begin{array}{l}\text { 2-[Biotin]- } \\
\text { AHA-cAMP }\end{array}$ & $\begin{array}{l}\text { CAMP } \\
\text { antibody }\end{array}$ & $\begin{array}{l}\text { 2-AH- } \\
\text { CGMP- } \\
\text { agarose }\end{array}$ & $\begin{array}{l}\text { 8-AET- } \\
\text { CGMP- } \\
\text { agarose }\end{array}$ & $\begin{array}{l}\text { 2-[Biotin]- } \\
\text { AH-CGMP }\end{array}$ & $\begin{array}{l}\text { cGMP } \\
\text { antibody }\end{array}$ \\
\hline AT3G13920 & $\begin{array}{l}\text { eukaryotic translation } \\
\text { initiation factor } 4 \mathrm{~A} 1\end{array}$ & & & B & & B & & & B & B & B & B & B & B & B & B & B \\
\hline AT3G12780 & phosphoglycerate kinase 1 & B & B & B & B & B & B & B & B & & & & & & & & \\
\hline AT1G42970 & $\begin{array}{l}\text { glyceraldehyde-3-phosphate } \\
\text { dehydrogenase B subunit }\end{array}$ & B & B & B & $2,3, B$ & B & B & B & B & & & & & & & & \\
\hline AT4G20360 & RAB GTPase homolog E1B & B & B & B & $2,3, \mathrm{~B}$ & B & B & B & B & & & & & & & & \\
\hline AT3G60750 & Transketolase & & B & B & B & B & B & B & B & & & & & & & & \\
\hline AT5G50920 & CLPC homologue 1 & B & B & B & B & B & B & B & & & & & & & & & \\
\hline AT4G37930 & $\begin{array}{l}\text { serine } \\
\text { transhydroxymethyltransferase } \\
1\end{array}$ & $2, B$ & B & $1, B$ & B & B & B & $2,3, B$ & & & & & & & & & \\
\hline AT3G14420 & Glycolate oxidase 1 & & B & & B & & & B & B & & & & & & & & \\
\hline AT4G09650 & ATP synthase delta subunit & & & B & & B & & B & B & & & & & & & & \\
\hline AT1G09340 & $\begin{array}{l}\text { chloroplast stem-loop binding } \\
\text { protein of } 41 \mathrm{kDA}\end{array}$ & & & 1 & B & B & & $2, B$ & & & & & & & & & \\
\hline $\begin{array}{l}\text { AT1G56330 } \\
\text { AT3G62560 } \\
\text { AT4G02080 }\end{array}$ & secretion-associated RAS 1B & & & & & & & & & B & & & & & B & & B \\
\hline AT4G27440 & $\begin{array}{l}\text { protochlorophyllide } \\
\text { oxidoreductase B }\end{array}$ & & B & & B & B & & & & & & & & & & & \\
\hline AT3G01500 & carbonic anhydrase 1 & & & B & & B & & & & & & & & & & & \\
\hline
\end{tabular}

The fraction in which the protein was identified is indicated with numbers 1-6 being the elution fractions (1 denotes the first and least stringent elution and 6 the final and most stringent elution) while B indicates that the protein was found in the bead fraction. For the cAMP baits the elutions were 1) $100 \mathrm{mM} \mathrm{GDP}$; 2) $100 \mathrm{mM} \mathrm{AMP}$; 3) $10 \mathrm{mM}$ cGMP; 4) $100 \mathrm{mM}$ cGMP; 5) $10 \mathrm{mM}$ cAMP and 6) $100 \mathrm{mM}$ cAMP. For the cGMP baits the elutions were 1) $100 \mathrm{mM}$ ADP; 2) $100 \mathrm{mM} \mathrm{GMP}$; 3) $10 \mathrm{mM}$ cAMP; 4) $100 \mathrm{mM}$ cAMP; 5) $10 \mathrm{mM}$ cGMP and 6) $100 \mathrm{mM}$ cGMP 
Table 2 Binding properties of the cyclic nucleotide binding protein candidates

\begin{tabular}{|c|c|c|c|c|c|c|c|c|}
\hline Accession & Description & $\begin{array}{l}\text { Nucleotide } \\
\text { binding }\end{array}$ & $\begin{array}{l}\text { Nucleotide binding } \\
\text { domain }\end{array}$ & Nucleotide binding site & $\begin{array}{l}\text { Alignment with } \\
\text { CNBD }\end{array}$ & $\begin{array}{l}\text { Putative } \\
\text { CNBD }\end{array}$ & NO PTM & $\begin{array}{l}\text { Site of NO } \\
\text { PTM }\end{array}$ \\
\hline AT3G13920 & $\begin{array}{l}\text { eukaryotic translation } \\
\text { initiation factor } 4 \mathrm{~A} 1\end{array}$ & ATP & $58-255$ & $83-90$ & GAF & 174-399 & S-nitrosylation & \\
\hline AT3G12780 & phosphoglycerate kinase 1 & ATP & & $432-435$ & CNB GAF & $\begin{array}{l}87-286 \\
171-335\end{array}$ & $\begin{array}{l}\text { S-nitrosylation } \\
\text { S-nitrosylation }\end{array}$ & \\
\hline AT1G42970 & $\begin{array}{l}\text { glyceraldehyde-3-phosphate } \\
\text { dehydrogenase B subunit }\end{array}$ & NAD (P) & $80-243$ & $91-92$ & CNB GAF & $\begin{array}{l}173-323 \\
83-288\end{array}$ & $\begin{array}{l}\text { S-nitrosylation } \\
\text { Y-nitration }\end{array}$ & \\
\hline AT4G20360 & RAB GTPase homolog E1B & GTP & $77-278$ & $\begin{array}{l}86-93 \text { 148-152 203- } \\
206\end{array}$ & & & $\begin{array}{l}\text { S-nitrosylation } \\
\text { S-nitrosylation }{ }^{H R} \\
\text { Y-nitration }\end{array}$ & \\
\hline AT3G60750 & Transketolase & & & & CNB GAF & $\begin{array}{l}213-408 \\
40-232\end{array}$ & $\begin{array}{l}\text { S-nitrosylation } \\
\text { Y-nitration }\end{array}$ & Y337 \\
\hline AT5G50920 & CLPC homologue 1 & ATP & $\begin{array}{l}294-434 \\
637-818\end{array}$ & $302-309645-652$ & & & & \\
\hline AT4G37930 & $\begin{array}{l}\text { serine transhydroxymethyltransferase } \\
1\end{array}$ & & & & CNB GAF & $\begin{array}{l}369-492 \\
262-458\end{array}$ & Y-nitration & \\
\hline AT3G14420 & Glycolate oxidase 1 & FMN & $13-355$ & 285-309 & GAF & $93-276$ & Y-nitration & \\
\hline AT4G09650 & ATP synthase delta-subunit & & & & & & & \\
\hline AT1G09340 & $\begin{array}{l}\text { chloroplast stem-loop } \\
\text { binding protein of } 41 \mathrm{kDA}\end{array}$ & NAD (P) & $54-235$ & & & & $\begin{array}{l}\text { S-nitrosylation } \\
\text { S-nitrosylation }{ }^{H R} \\
\text { Y-nitration }\end{array}$ & \\
\hline AT4G27440 & $\begin{array}{l}\text { protochlorophyllide } \\
\text { oxidoreductase B }\end{array}$ & NAD (P) & $\begin{array}{l}84-234 \\
270-366\end{array}$ & & CNB & $77-279$ & Y-nitration & \\
\hline AT3G01500 & carbonic anhydrase 1 & & & & GAF & $141-345$ & $\begin{array}{l}\text { S-nitrosylation } \\
\text { S-nitrosylation } \\
\text { YR } \\
\text { Y-nitration }\end{array}$ & C280 \\
\hline
\end{tabular}

Annotated nucleotide binding domains and nucleotide binding sites of the candidate CNBPs were extracted from the Unip
extrapolated from Figs. 1 and 2. Evidence of NO-induced PTM and the PTM site was obtained from the literature [79-82] 


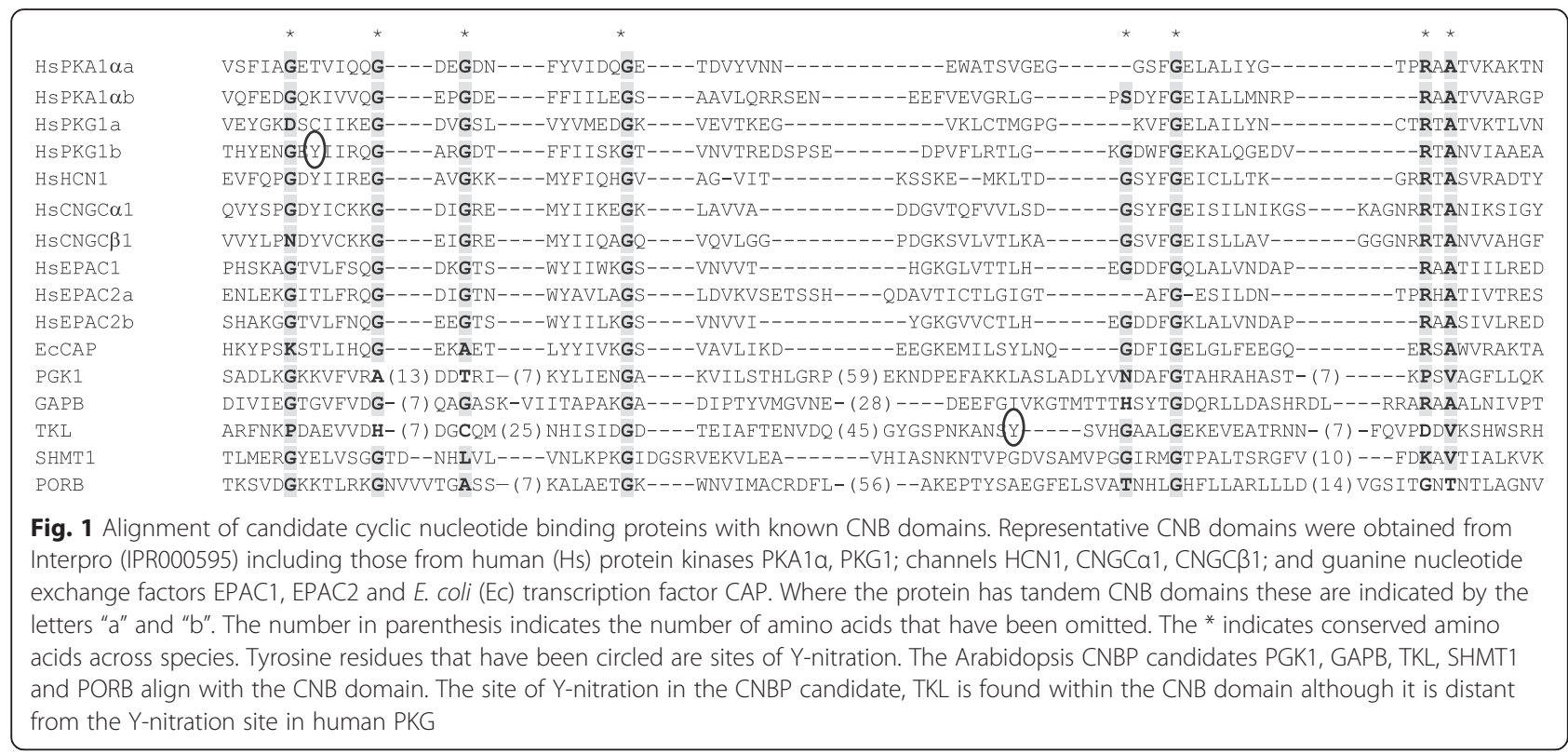

nearby cysteine is conserved in all plant and bacterial phytochromes (Additional file 5). This revealed that a number of candidate CNBPs are modified by NO and, for TKL and CA1, the PTM site lies within the putative CNBD supporting that $\mathrm{CNs}$ and $\mathrm{NO}$ can modify these proteins at the same site and presenting a possible mechanism of crosstalk between these second messengers.

\section{Six of the candidate CNBPs are Calvin cycle and photorespiratory enzymes}

The TAIR descriptions further revealed that a number of the candidate CNBPs function in the Calvin cycle or photorespiration pathway. The Calvin cycle utilizes ATP and $\mathrm{NADPH}$ to assimilate $\mathrm{CO}_{2}$ into carbon skeletons [84] while photorespiration consumes ATP and NADH to regenerate $\mathrm{CO}_{2}$; and is important for limiting photoinhibition, nitrate assimilation and ROS signaling [85]. The positions of the candidate CNBPs in the Calvin cycle and photorespiration pathways are illustrated in Fig. 3.

The Calvin cycle is connected to the photorespiration pathway by RIBULOSE-1, 5-BISPHOSPHATE CARBOXYLASE/OXYGENASE (RUBISCO) that either binds $\mathrm{CO}_{2}$ or $\mathrm{O}_{2}$ to catalyse the carboxylation or oxygenation of D-ribulose-1, 5-bisphosphate (RuBP) to initiate the Calvin cycle or photorespiration, respectively. The balance between the Calvin cycle and photorespiration is determined, in part, by the supply of $\mathrm{CO}_{2}$ to RUBISCO [85]. This is controlled by the candidate CNBP, CA1 which converts

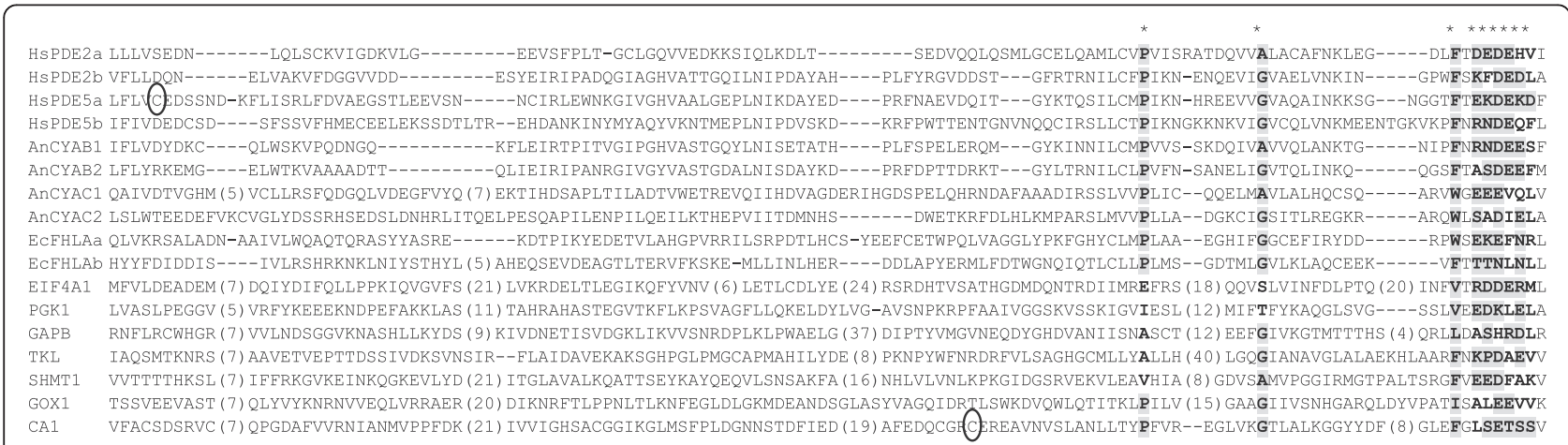

Fig. 2 Alignment of candidate cyclic nucleotide binding proteins with known GAF domains. Representative GAF domains (IPR003018) include those from human (Hs) phosphodiesterases PDE2, PDE5; Anabaena sp. PCC 7120 (An) adenylyl cyclases CYAB1, CYAB2, CYAC1, CYAC2; and E. coli (Ec) FhIA. Where the protein has tandem GAF domains these are indicated by the letters "a" and "b". The number in parenthesis indicates the number of amino acids that have been omitted. The * indicates conserved amino acids across species. The cysteine residues that have been circled are sites of S-nitrosylation. The Arabidopsis CNBP candidates EIF4A1, PGK1, GAPB, TKL, SHMT1, GOX1 and CA1 align with the GAF domain. The site of S-nitrosylation in the CNBP candidate CA1 is found within the GAF domain although it is distant from the S-nitrosylation site in human PDE5. 


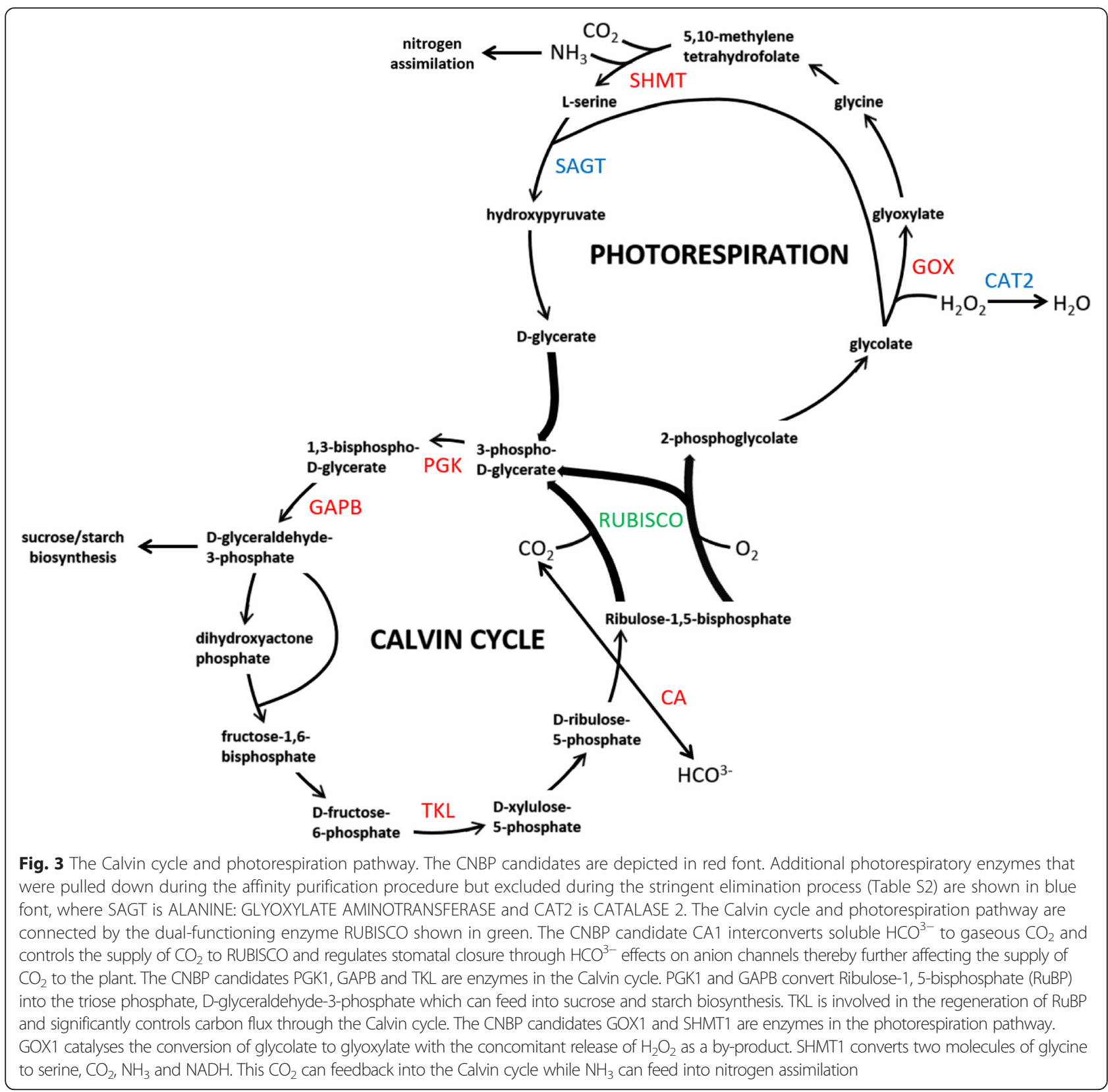

$\mathrm{HCO}^{3-}$ to $\mathrm{CO}_{2}$ at the site of RUBISCO [86]. Thereafter, the initial reductive steps of the Calvin cycle are performed by PKG and GAPB that convert the product of RuBP carboxylation to a triose phosphate that can feed into sucrose and starch biosynthesis. Later in the Calvin cycle, TKL regenerates RuBP and regulation of TKL significantly controls carbon flux through the cycle [84]. Therefore the candidate CNBPs CA1, PKG, GAPB and TKL are key enzymes that regulate the supply, removal and flux of carbon through the Calvin cycle.

Early in the photorespiration pathway, GOX1 catalyses the oxidation of glycolate to glyoxylate with the concomitant release of $\mathrm{H}_{2} \mathrm{O}_{2}$. Later in the pathway SHMT1 converts two molecules of glycine to serine, $\mathrm{CO}_{2}, \mathrm{NH}_{3}$ and NADH. Thus the candidate CNBPs, GOX1 and SHMT1 are key enzymes in the photorespiration pathway that catalyse reactions whose by-products $\left(\mathrm{H}_{2} \mathrm{O}_{2}\right.$, $\mathrm{NH}_{3}$ and $\mathrm{CO}_{2}$ ) are important for ROS signaling, nitrogen assimilation or feedback to the Calvin cycle.

Candidate CNBPs function in $\mathrm{H}_{2} \mathrm{O}_{2}$ signaling and defence While the enzymatic activities of the above six candidate CNBPs are known and their functions related, there is little information available for the other six candidate CNBPs. Moreover, the candidate CNBPs with known enzyme activities are involved in primary metabolism so it 
Table 3 Expression correlation matrix of cyclic nucleotide binding protein candidates

\begin{tabular}{|c|c|c|c|c|c|c|c|c|c|c|c|c|}
\hline EIF4A & PGK1 & GAPB & RABE1b & TKL & CLPC1 & SHMT1 & GOX1 & ATPD & CSP41B & PORB & $\mathrm{CA} 1$ & \\
\hline \multirow[t]{12}{*}{1} & $x$ & $x$ & $x$ & $x$ & $x$ & $x$ & $x$ & $x$ & $x$ & $x$ & $x$ & EIF4A \\
\hline & 1 & 0.956 & 0.876 & 0.877 & 0.834 & 0.893 & 0.897 & 0.910 & 0.958 & $x$ & 0.947 & PGK1 \\
\hline & & 1 & 0.900 & 0.886 & 0.783 & 0.851 & 0.923 & 0.922 & 0.973 & $x$ & 0.940 & GAPB \\
\hline & & & 1 & 0.813 & 0.736 & 0.770 & 0.856 & 0.881 & 0.881 & $x$ & 0.867 & RABE1b \\
\hline & & & & 1 & 0.77 & 0.763 & 0.818 & 0.826 & 0.859 & $x$ & 0.858 & TKL \\
\hline & & & & & 1 & 0.784 & 0.756 & 0.718 & 0.785 & $x$ & 0.751 & CLPC1 \\
\hline & & & & & & 1 & 0.803 & 0.756 & 0.817 & $x$ & 0.839 & SHMT1 \\
\hline & & & & & & & 1 & 0.881 & 0.920 & $x$ & 0.898 & GOX1 \\
\hline & & & & & & & & 1 & 0.942 & $x$ & 0.900 & ATPD \\
\hline & & & & & & & & & 1 & $x$ & 0.946 & CSP41B \\
\hline & & & & & & & & & & 1 & $x$ & PORB \\
\hline & & & & & & & & & & & 1 & CA1 \\
\hline
\end{tabular}

Expression correlation matrix detailing the level of co-expression (expression correlation $r$-value) that the identified CNBP candidates share with each other. $\mathrm{X}$ denotes that the shared $r$-value was below 0.7

is unclear under what circumstances their regulation is important. Therefore a transcriptional co-expression, gene ontology (GO) and stimulus-specific expression analysis was performed, to better understand the functions of the candidate CNBPs [87].

The transcriptional co-expression analysis was conducted to determine the level of co-expression shared by each of the candidate CNBPs and identify potential functional relationships between their genes/proteins. It was determined that expression of ten of the 12 candidate CNBPs is highly correlated including the Calvin cycle and photorespiratory genes and the less well functionally characterized ATPD, RABE1b, CLPC1 and CSP41B (Table 3). The high level of co-expression of these four genes with the Calvin cycle and photorespiratory genes suggests that they may have functional roles in these processes. The two candidate CNBPs that were not significantly correlated included EIF4A and PORB.

A GO analysis of the ten expression correlated CNBP candidates (from Table 3), using the TAIR database, revealed that seven are annotated to function in the defence response while eight have GO terms related to $\mathrm{H}_{2} \mathrm{O}_{2}$ signaling (Table 4). Only RABE1b did not have $\mathrm{GO}$ terms associated with either defence or $\mathrm{H}_{2} \mathrm{O}_{2}$, however its co-expression with the other expression correlated CNBP candidates suggests that it plays a role in these processes [23, 88]. This analysis supports that the expression correlated CNBP candidates function in $\mathrm{H}_{2} \mathrm{O}_{2}$ signaling and the defence response. These functions could be related as $\mathrm{H}_{2} \mathrm{O}_{2}$ signaling is critical to the defence response, particularly the hypersensitive response (HR) during incompatible interactions with avirulent pathogens [89]. In support of this, six of the expression correlated CNBP candidates have $\mathrm{GO}$ annotations for both $\mathrm{H}_{2} \mathrm{O}_{2}$ signaling and the defence response while five have GO terms for "incompatible interaction"; "plant-type HR" or "regulation of plant-type HR".

Finally, an in silico global expression analysis was performed to identify conditions that induce differential expression of the ten expression correlated CNBP candidates. Genevestigator was used to screen the publically available microarray data and identify experiments of interest. The expression correlated CNBP candidates were found to be induced in response to light and repressed in response to nitrate starvation, like other photorespiratory genes [85]; and repressed in plants infected with Pseudomonas (Fig. 4). The stimulus-specific expression profile confirms that the expression correlated CNBP candidates have similar expression profiles and supports that they play a role in photorespiration and the defence response.

\section{Glycolate oxidase activity is repressed by cGMP and nitric oxide}

Since a number of the expression correlated CNBP candidates are modified by $\mathrm{NO}$ and annotated to function in $\mathrm{H}_{2} \mathrm{O}_{2}$ signalling and the defence response, it is conceivable that $\mathrm{CN}$ binding and NO-mediated PTM could regulate the activity of these proteins to modify $\mathrm{H}_{2} \mathrm{O}_{2}$ signalling in the plant response to pathogens. To test this hypothesis, the activity of GOX1 was examined as it has been shown to produce $\mathrm{H}_{2} \mathrm{O}_{2}$ during the defence response [70].

The effect of cGMP and NO on GOX activity was measured during the plant response to pathogens. Plants infected for $24 \mathrm{~h}$ with avirulent Pst DC3000 AvrRpm1, but not virulent Pst DC3000, were found to have significantly $(p=0.0276)$ increased GOX activity (Fig. 5). When applied alone, neither cGMP nor NO had any effect on Pst DC3000 AvrRpm1-induced GOX activity. However, in combination, cGMP and NO significantly $(p=0.0400)$ 
Table 4 Gene ontology biological process annotations of the expression correlated cyclic nucleotide binding protein candidates

\begin{tabular}{|c|c|c|c|}
\hline Accession & Description & Defence response & $\mathrm{H}_{2} \mathrm{O}_{2}$ signaling \\
\hline AT3G12780 & phosphoglycerate kinase 1 & $\begin{array}{l}\text { defence response to bacterium, } \\
\text { defence response, incompatible interaction }\end{array}$ & $\begin{array}{l}\text { hydrogen peroxide } \\
\text { catabolic process }\end{array}$ \\
\hline AT1G42970 & $\begin{array}{l}\text { glyceraldehyde-3-phosphate } \\
\text { dehydrogenase B subunit }\end{array}$ & defence response to bacterium & $\begin{array}{l}\text { hydrogen peroxide } \\
\text { catabolic process }\end{array}$ \\
\hline AT4G20360 & RAB GTPase homolog E1B & & \\
\hline AT3G60750 & Transketolase & & $\begin{array}{l}\text { hydrogen peroxide } \\
\text { catabolic process }\end{array}$ \\
\hline AT5G50920 & CLPC homologue 1 & & $\begin{array}{l}\text { hydrogen peroxide } \\
\text { catabolic process }\end{array}$ \\
\hline AT4G37930 & serine transhydroxymethyl-transferase 1 & $\begin{array}{l}\text { defence response to bacterium, defence } \\
\text { response, incompatible interaction, } \\
\text { plant-type hypersensitive response, } \\
\text { salicylic acid biosynthetic process }\end{array}$ & \\
\hline AT3G14420 & Glycolate oxidase 1 & defence response to bacterium & $\begin{array}{l}\text { hydrogen peroxide } \\
\text { biosynthetic process }\end{array}$ \\
\hline AT4G09650 & ATP synthase delta-subunit & $\begin{array}{l}\text { defence response to bacterium, defence } \\
\text { response to fungus, defence response, } \\
\text { incompatible interaction, detection of } \\
\text { biotic stimulus, jasmonic acid mediated } \\
\text { signaling pathway, negative regulation of } \\
\text { defence response, regulation of plant-type } \\
\text { hypersensitive response, regulation of response } \\
\text { to biotic stimulus, response to chitin, } \\
\text { salicylic acid biosynthetic process, } \\
\text { systemic acquired resistance, salicylic acid } \\
\text { mediated signaling pathway }\end{array}$ & $\begin{array}{l}\text { regulation of hydrogen } \\
\text { peroxide metabolic } \\
\text { process }\end{array}$ \\
\hline AT1G09340 & $\begin{array}{l}\text { chloroplast stem-loop binding } \\
\text { protein of } 41 \mathrm{kDA}\end{array}$ & $\begin{array}{l}\text { defence response to bacterium, defence } \\
\text { response to fungus, defence response, } \\
\text { incompatible interaction, detection of } \\
\text { biotic stimulus, jasmonic acid mediated } \\
\text { signaling pathway, negative regulation of } \\
\text { defence response, regulation of plant-type } \\
\text { hypersensitive response, regulation of } \\
\text { response to biotic stimulus, salicylic acid } \\
\text { biosynthetic process, systemic acquired resistance, } \\
\text { salicylic acid mediated signaling pathway }\end{array}$ & $\begin{array}{l}\text { regulation of hydrogen } \\
\text { peroxide metabolic } \\
\text { process }\end{array}$ \\
\hline AT3G01500 & carbonic anhydrase 1 & $\begin{array}{l}\text { defence response to bacterium, defence } \\
\text { response to fungus, defence response to } \\
\text { fungus, incompatible interaction, defence } \\
\text { response, incompatible interaction, detection } \\
\text { of biotic stimulus, jasmonic acid mediated } \\
\text { signaling pathway, negative regulation of } \\
\text { defence response, regulation of plant-type } \\
\text { hypersensitive response, regulation of response } \\
\text { to biotic stimulus, response to chitin, salicylic acid } \\
\text { biosynthetic process, systemic acquired resistance, } \\
\text { salicylic acid mediated signaling pathway }\end{array}$ & $\begin{array}{l}\text { regulation of hydrogen } \\
\text { peroxide metabolic } \\
\text { process }\end{array}$ \\
\hline
\end{tabular}

The $\mathrm{GO}$ biological process terms related to the plant defence response against pathogens and $\mathrm{H}_{2} \mathrm{O}_{2}$ signaling were downloaded from TAIR for the ten expression correlated CNBPs extracted from Table 3

repressed Pst DC3000 AvrRpm1-induced GOX activity to basal levels. These results indicate that NO and cGMP repress GOX activity, and thus $\mathrm{H}_{2} \mathrm{O}_{2}$ production, during the defence response which is consistent with regulation of GOX1 through cGMP binding and NO-mediated PTM.

\section{Discussion}

In plants, cGMP and cAMP have been shown to play an important role in physiological processes including stomatal closure and the defence response $[10,16]$. While a number of NCs have been identified in Arabidopsis and demonstrated to synthesize CNs, little is known about the cytosolic target proteins and thus the downstream mechanisms of cGMP and cAMP signaling. Here, we attempted to elucidate these mechanisms using an affinity pull-down approach to identify CNBPs.

\section{Experimental protocol validation}

Twelve candidate CNBPs were identified from Arabidopsis leaf and callus extracts using an affinity pull- 


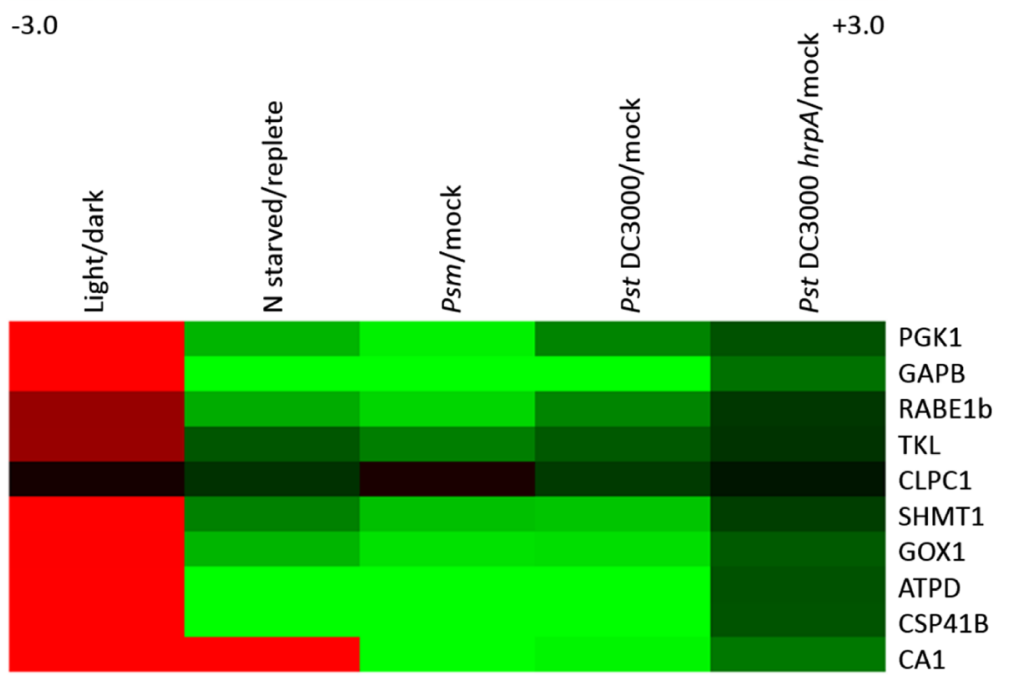

Fig. 4 Gene expression profiling of the expression correlated cyclic nucleotide binding protein candidates. Heat map to show that the ten expression correlated CNBP candidates (extracted from Table 3) are co-expressed and differentially expressed in the selected microarray experiments. Experiments chosen were light vs. dark grown seven day old seedlings; seven day old seedlings that were shifted to nitrogen starved vs. replete media for a further $48 \mathrm{~h}$; Col-0 infected with $10^{5} \mathrm{cfu} \mathrm{cm}^{-2}$ virulent Psm ES4326 for $24 \mathrm{~h}$ vs. mock infected; Col-0 infected with $10^{8} \mathrm{cfu} \mathrm{cm}^{-2}$ virulent Pst DC3000 or $10^{8} \mathrm{cfu} \mathrm{cm}^{-2}$ Pst DC3000 hrpA mutant (lacks the type III protein secretion system that delivers virulence effector proteins into host cells) for $7 \mathrm{~h}$ vs. mock infected. The scale bar shows the intensity of the $\log _{2}$ transformed fold change values used to generate the heat map

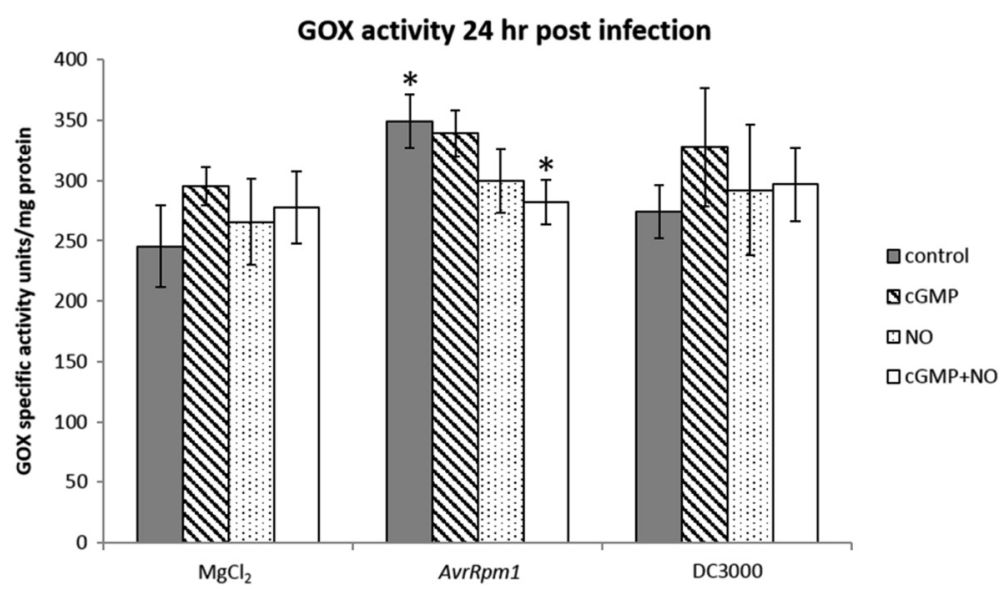

Fig. 5 Glycolate oxidase activity in plants inoculated with avirulent and virulent Pseudomonas. The leaves of four week old Col-0 plants were pressure inoculated with either $10^{6} \mathrm{cfu} \mathrm{ml}^{-1}$ avirulent Pst DC3000 AvrRpml or virulent Pst DC3000 or $10 \mathrm{mM} \mathrm{MgCl}_{2}$ (control). The effect of $\mathrm{NO}$ and cGMP during infection was examined by including $50 \mu \mathrm{M}$ 8-Br cGMP or $50 \mu \mathrm{M}$ diethylamine NONOate either separately or in combination, in the bacterial suspension at the time of infection. The infected leaves were harvested at $24 \mathrm{~h}$ post infection and GOX activity measured. Leaf proteins were extracted and incubated with sodium glycolate, O-dianisidine and horseradish peroxidase. GOX activity catalyses the conversion of the sodium glycolate substrate to glyoxylate, releasing $\mathrm{H}_{2} \mathrm{O}_{2}$. The $\mathrm{H}_{2} \mathrm{O}_{2}$ reacts with O-dianisidine in the presence of horseradish peroxidase to produce the coloured O-dianisidine radical which can be quantified spectrophotometrically at $440 \mathrm{~nm}$. GOX activity was found to be significantly induced ( $p=0.0276$ ) by ArvRpm1 relative to the $\mathrm{MgCl}_{2}$ control and this activity was significantly suppressed $(p=0.0400)$ by the combined treatment with NO and cGMP. Error bars represent standard error of the mean $(n=6)$ and statistical significance was determined using a student's t-test with the asterisks denoting significant $p$ values $<0.05$ 
down technique with synthetic cAMP and cGMP baits and $\mathrm{CN}$-specific antibodies (Table 1). Candidate CNBPs displayed high affinity binding but lacked specificity for cAMP or cGMP baits. In animal studies similar observations have been made for the well-known CNBPs, PKA and PKG $[61,90]$. Indeed, cAMP and cGMP bind each other's kinases and PDEs suggesting that extensive cross-talk occurs between cAMP and cGMP signaling pathways [91]. The majority of candidate CNBPs identified were isolated from leaf extracts. This could be attributed to $\mathrm{CN}$ signaling being prevalent in leaf tissue where CNs function in chloroplast development, stomatal signaling and stress responses $[9,10,17,18]$. In contrast, undifferentiated callus may lack functional components of these processes.

There have been three previous attempts to identify CNBPs in plants using synthetic $\mathrm{CN}$ baits however each of these studies used only one $\mathrm{CN}$ bait and produced limited information. One study failed to identify the interacting proteins [92]. The other two studies identified nucleoside diphosphate kinases which were detected in this study and in animal studies but were discarded as low affinity binding proteins as they were displaced during the sequential elution process $[10,93]$. The only other protein identified was GAPB which was also identified here [93].

\section{Sequence analysis of candidate CNBPs}

Sequence analysis revealed that none of the identified Arabidopsis candidate CNBPs contain annotated CNBDs. The majority of Arabidopsis proteins harbouring CNBDs are membrane-associated channels and $\mathrm{K}^{+}$ transporters. These are unlikely to be present in our experiments since the protein extraction buffer would most likely isolate soluble proteins and not hydrophobic membrane proteins. Consistent with this, animal membrane associated CNBPs have proved difficult to purify using $\mathrm{CN}$ baits [62]. The aim of this study however, was to identify unknown downstream components of Arabidopsis $\mathrm{CN}$ signaling pathways, such as $\mathrm{CN}$-dependent protein kinases and PDEs which are soluble proteins. Additionally, since CNs are synthesised in the cytosol, it is reasonable to assume that direct targets of $\mathrm{CNs}$ would be found in the soluble protein fraction.

In contrast to the lack of annotated CNBDs, a number of the candidate CNBPs are annotated to bind related nucleotides such as ATP or GTP (Table 2). It is considered unlikely that these candidate CNBPs bind the $\mathrm{CN}$ baits with low affinity because of their affinity for similar nucleotides since they were not displaced during the sequential elution process. Furthermore all of the candidate CNBPs, except CA1, were immunoaffinity purified with antibodies which are highly specific to cAMP and cGMP. This is significant as it is possible that proteins bind the synthetic $\mathrm{CNs}$ due to excess $\mathrm{CN}$ concentrations. However, in the immunoaffinity pull-downs no exogenous CNs were added so the interaction was dependent on the protein binding to endogenous CNs. In animals, PKA and PKG bind ATP through their kinase domains while EPACs bind GTP through guanine nucleotide exchange factor domains. Thus it is not unexpected that CNBPs bind other nucleotides in addition to CNs.

Alignment of the candidate CNBPs with known CNBDs, revealed that eight of the 12 candidate CNBPs contain sequences that are similar to CNB or GAF domains (Figs. 1 and 2). There is no detectable overlap between the abovementioned nucleotide binding sites and the putative CNBDs, supporting that the candidate CNBPs possess distinct $\mathrm{CN}$ and nucleotide binding sites (Table 2). These CNB- and GAF-like sequences are not annotated in the protein databases as search motifs employed by these databases are conservative; whereas the CNBD-like sequences identified here allow for single mismatches, insertions or deletions or larger gap regions between stretches of conserved amino acids. Importantly similar CNBD-like sequences have been identified in Dictyostelium cGMP binding proteins (GbpA-D), and these have been shown to bind CNs (Additional file 4) $[94,95]$. Another possibility is that plants have evolved unique CNBDs that have yet to be annotated. The experimental design here allows for this possibility; however we could not identify any novel CNBDs from the alignments.

\section{Nitric oxide-mediated post translational modification}

In animals, NO is intrinsically linked to cGMP signaling since NO stimulates the soluble guanylyl cyclase (GC) to produce cGMP [96]. It is plausible that a similar $\mathrm{NO} /$ cGMP signaling pathway operates in plants since NO has been shown to induce cGMP synthesis in plants $[12,15]$ and a NO-responsive GC was recently identified in Arabidopsis [26].

The finding that ten of the 12 candidate CNBPs are modified by NO-induced PTMs, S-nitrosylation and Ynitration, (Table 2) was interesting as it presents a potential mechanism for cross-talk between cGMP and NO signalling pathways. This result is particularly significant when considering that only 120 and 130 Arabidopsis proteins have been demonstrated to be S-nitrosylated and Ynitrated, respectively under basal conditions and/or during the HR [79-82]. It was not possible to detect either PTM in our experiments; not surprisingly as these PTMs are in low abundance and labile and thus typically studied using the biotin-switch technique. Furthermore, S-nitrosylation and Y-nitration may have been destroyed during the electrophoresis and tryptic digest which included reducing agents $[80,81]$. Even using the biotin-switch technique, PTM sites have been difficult to detect. Nevertheless for 
the candidate CNBPs, TKL and CA1, the PTMs have been mapped and in both cases the PTM site is contained within the putative CNBD (Figs. 1 and 2). Conservation of these cysteine and tyrosine residues across kingdoms is indicative of functional importance (Additional files 4 and 5).

In agreement with our finding that the Arabidopsis candidate CNBPs are subject to NO-mediated PTM, NO has been shown to modify animal CNBPs. There is evidence that Y-nitration of PKA decreases affinity for cAMP binding, although the Y-nitration site remains unknown [97]. Similarly, Y-nitration of PKG at Y247, within the CNB domain, has been shown to decrease PKG activity [98]. This site lies upstream of the Y-nitration site in TKL, however a tyrosine at this position is conserved in $\mathrm{HCNs}$ and CNGCs and in the candidate CNBP, SHMT1 that is also subject to Y-nitration (Fig. 1; Additional file 4). Additionally, there is evidence for S-nitrosylation of PDE5A at C181, within the GAF domain, that reduces PDE activity by interfering with cGMP binding [99]. This site is not conserved in other known GAF domains however there is a similar site in GAPB, a CNBP candidate that is subject to S-nitrosylation (Fig. 2; Additional file 5). Therefore, Ynitration of the $\mathrm{CNB}$ domain and S-nitrosylation of the GAF domain may be a general mechanism of NOmediated regulation of CNBPs and cross-talk between cGMP and NO signaling pathways that is conserved across plant and animal kingdoms.

\section{Functions of the candidate CNBPs}

Six of the identified Arabidopsis candidate CNBPs are key enzymes in the Calvin cycle and photorespiration pathway (Fig. 3). Transcriptional co-expression analysis revealed that the Calvin cycle and photorespiratory genes are significantly co-expressed with the less well functionally characterized CNBPs, ATPD, RABE1b, CLPC1 and CSP41B (Table 3). These lessor known genes may play a role in these pathways since a number of studies have shown that co-expressed genes often function together in common biological processes [100, 101].

Modulation of the activities of these enzymes, through $\mathrm{CN}$ binding or NO-mediated PTM, may affect the balance between respiration and photorespiration which would alter $\mathrm{H}_{2} \mathrm{O}_{2}$ levels synthesized during photorespiration [85]. In support of this, eight of the abovementioned ten expression correlated CNBP candidates are annotated to function in $\mathrm{H}_{2} \mathrm{O}_{2}$ signaling (Table 4). Previously it has been shown that the activity of GOX1, the photorespiratory enzyme that produces $\mathrm{H}_{2} \mathrm{O}_{2}$ (Fig. 3), is modified by $\mathrm{NO}$ and this has been proposed to regulate $\mathrm{H}_{2} \mathrm{O}_{2}$ levels in response to abiotic stresses [102]. We have shown that GOX1 binds CNs and contains a GAFlike domain, suggesting that $\mathrm{CNs}$ could also affect the activity of GOX1 to regulate $\mathrm{H}_{2} \mathrm{O}_{2}$ levels.
In plants cGMP, $\mathrm{NO}$ and $\mathrm{H}_{2} \mathrm{O}_{2}$ signaling pathways have well established roles in two processes: stomatal closure and the defence response, particularly the HR during incompatible interactions with avirulent pathogens [2, 16, 103-105]. During ABA-mediated stomatal closure, ABA-induced $\mathrm{NO}$ and $\mathrm{H}_{2} \mathrm{O}_{2}$ stimulate cGMP synthesis which leads to increases in cytosolic $\mathrm{Ca}^{2+}$, likely through cGMP activation of CNGCs [10]. Subsequently Joudoi and colleagues have shown that reactive nitrogen species (produced when ROS react with NO) react with cGMP to produce 8 -Nitro-cGMP and this triggers the increase in cytosolic $\mathrm{Ca}^{2+}$ which then acts on SLAC1 anion channels to induce stomatal closure [105]. Two CNGCs, CNGC5 and CNGC6, are likely to be responsible for these cGMP activated $\mathrm{Ca}^{2+}$ currents in guard cells [38]. However, the fact that $c n g c 5 c n g c 6$ double mutants are not impaired in ABA-induced stomatal closure suggests that there are other factors involved, consistent with the observation that cGMP is required but not sufficient for ABA-induced stomatal closure [10]. We would suggest that these other factors involved in ABA-induced stomatal closure include the identified $\mathrm{CNBP}$ candidates. For example, CA1 could be a downstream target of the cGMP/NO signaling pathway that operates during ABAinduced stomatal closure since our results show that it binds $\mathrm{CNs}$ and it has previously been shown to be Snitrosylated [83] and regulate stomatal closure through $\mathrm{HCO}_{3}^{-}$effects on SLAC1 [106, 107].

Similarly, we propose that the expression correlated CNBP candidates could be direct targets of the pathogen-induced cGMP/NO signaling pathway. In support of this, the expression correlated CNBP candidates are annotated to function in the defence response, specifically incompatible interactions and the HR (Table 4). Additionally, their expression is repressed in response to virulent bacterial pathogens, Psm and Pst DC3000, as well as in response to the non-pathogenic Pst DC3000 $h r p A$ mutant, supporting the annotated function in plant defence and suggesting that plants down regulate the expression of these genes as part of pathogen associated molecular pattern (PAMP) triggered immunity (Fig. 4). Finally, mutant studies provide further evidence that CA1, GOX1 and SHMT1 function in the defence response. Specifically cal mutants are compromised in their defence against avirulent Pst DC3000 avrB; gox 1 mutants are compromised in their defence against virulent Pst DC3000 and non-host P. syringae pv syringae and $P$. syringae pv tabaci and shmt1 mutants and compromised in their defence against virulent Pst DC3000 and avirulent Pst DC3000 AvrRpm1 [70, 83, 108]. The compromised defence response phenotypes of these mutants may be due to defects in their $\mathrm{H}_{2} \mathrm{O}_{2}$ levels as gox 1 mutants produce less $\mathrm{H}_{2} \mathrm{O}_{2}$ and shmt1 mutants produce more $\mathrm{H}_{2} \mathrm{O}_{2}$ in response to stress. 
Here we showed that GOX activity is induced by avirulent Pst DC3000 AvrRpm1 and this response is inhibited by a combination of NO and cGMP treatment (Fig. 5). It was somewhat surprising that neither NO nor cGMP alone was able to inhibit GOX activity because NO has been shown to induce cGMP synthesis in plants $[10,12,15]$. This could suggest that there are NOmediated cGMP-independent pathways required for inhibition of GOX activity, for example NO-induced PTM [104]. Similarly, there may be cGMP pathways that are independent of upstream NO signalling that are required for inhibition of GOX activity. For example, cGMP synthesis via ligand-stimulated particulate GCs may be required for a full cGMP response to avirulent Pst DC3000 AvrRpm1 and in support of this a leucine rich repeat containing Toll-like receptor has recently been shown to contain an active GC domain [109]. Therefore, NO-mediated cGMP-dependent and cGMP-independent pathways as well as cGMP pathways that are independent of NO may be required for inhibition of GOX activity.

The finding that Pst DC3000 AvrRpm1-induced GOX activity was inhibited by NO and cGMP supports that $\mathrm{NO}$ and cGMP signalling pathways can converge to modify GOX1 activity, and thus $\mathrm{H}_{2} \mathrm{O}_{2}$ production under conditions that elicit a HR. There are conflicting reports that place $\mathrm{NO}$ upstream and downstream of $\mathrm{H}_{2} \mathrm{O}_{2}$ in the plant response to pathogens [110] and there is evidence that cGMP stimulates $\mathrm{H}_{2} \mathrm{O}_{2}$ production $[111,112]$ although whether or not this happens in response to pathogens remains to be determined. We speculate that NO and cGMP inhibition of GOX activity is a negative feedback mechanism to turn off the $\mathrm{H}_{2} \mathrm{O}_{2}$ signal and prevent uncontrolled cell death during the HR. In support of this, NO-mediated PTM has been shown to inhibit NADPH oxidase activity [113] and stimulate ascorbate peroxidase activity [114], the combined effect of which would reduce $\mathrm{H}_{2} \mathrm{O}_{2}$ levels and this has been suggested to act as a negative feedback loop to limit the HR. This does not exclude the possibility that NO and cGMP stimulate $\mathrm{H}_{2} \mathrm{O}_{2}$ production at earlier time points in the response of Arabidopsis to avirulent Pst DC3000 AvrRpm1.

While we do not know how NO and cGMP affect the activity of the other CNBP candidates, we speculate that NO and cGMP can also modify their activities to finetune $\mathrm{H}_{2} \mathrm{O}_{2}$ signaling during the defence response.

\section{Conclusions}

In conclusion, the Calvin cycle (PKG, GAPB and TKL) and photorespiratory enzymes (GOX1 and SHMT1) and the associated CA1 contain CNBD-like sequences and are modified by NO. Expression of these genes is correlated and they have GO annotations that suggest they function in $\mathrm{H}_{2} \mathrm{O}_{2}$ signaling the defence response. We have demonstrated that cGMP and NO treatment can modify the activity of at least one of the CNBP candidates, GOX1, that produces $\mathrm{H}_{2} \mathrm{O}_{2}$ in response to Pst DC3000 AvrRpm1. Therefore, the identified CNBP candidates have plausible roles in plant $\mathrm{CN}$-mediated processes and we propose that they function together as points of cross-talk between $\mathrm{CN}$, $\mathrm{NO}$ and $\mathrm{H}_{2} \mathrm{O}_{2}$ signaling during the defence response.

\section{Ethics approval and consent to participate}

Not applicable

\section{Consent for publication}

Not applicable

\section{Availability of data and materials}

The datasets supporting the conclusions of this article are included within the article and its additional files.

\section{Additional files}

Additional file 1: Experimental design to affinity purify CNBPs from Arabidopsis. (PDF $101 \mathrm{~kb}$ )

Additional file 2: Arabidopsis proteins affinity purified by CN baits following negative subtraction. (PDF $113 \mathrm{~kb}$ )

Additional file 3: Peptides identified in Arabidopsis CNBP candidates. (PDF $114 \mathrm{~kb}$ )

Additional file 4: Alignment of CNBP candidates with known CNB domains. (PDF $242 \mathrm{~kb}$ )

Additional file 5: Alignment of CNBP candidates with known GAF domains. (PDF $101 \mathrm{~kb}$ )

\section{Abbreviations}

ATPD: atp synthase delta-subunit; CA1: carbonic anhydrase 1;

CAMP: adenosine 3', 5'-cyclic monophosphate; cGMP: guanosine 3', 5'-cyclic monophosphate; CLPC1: caseinolytic protease c homolog 1; CN: cyclic nucleotide; CNB: cyclic nucleotide binding; CNBD: cyclic nucleotide binding domain; CNBP: cyclic nucleotide binding protein; CNGC: cyclic nucleotidegated channel; CSP41B: chloroplast stem-loop binding protein of $41 \mathrm{kDa}$; EIF4A1: eukaryotic translation initiation factor 4A1; EPAC: exchange protein activated by CAMP; GAF: CGMP binding PDEs, Anabaena adenylyl cyclase and E. coli FhIA; GAPB: glyceraldehyde-3-phosphate dehydrogenase b subunit; GC: guanylyl cyclase; GO: gene ontology; GOX1: glycolate oxidase; $\mathrm{H}_{2} \mathrm{O}_{2}$ : hydrogen peroxide; $\mathrm{HCN}$ : hyperpolarization-activated $\mathrm{CN}$-modulated channel; HR: hypersensitive response; MS: mass spectrometry; NC: nucleotidyl cyclase; NO: nitric oxide; PDE: phosphodiesterase; PGK1: phosphoglycerate kinase 1; PKA: CAMP-dependent protein kinase; PKG: CGMP-dependent protein kinase; PORB: protochlorophyllide oxidoreductase B;

Psm: Pseudomonas syringae pv maculicola; Pst: Pseudomonas syringae pv tomato; PTM: post-translationally modified; RABE1b: ras-related in brain GTPase homolog E1b; ROS: reactive oxygen species; SHMT1: serine hydroxymethyltransferase 1; TKL: transketolase.

\section{Competing interests}

The authors declare that they have no competing interests.

\section{Authors' contributions}

LD: conceived and designed the study, performed the affinity purification and enzyme assays, carried out the sequence alignment, contributed to the transcriptional co-expression, gene ontology and stimulus-specific expression analysis and drafted the manuscript. SM: contributed to the transcriptional co-expression, gene ontology and stimulus-specific expression analysis and 
helped draft the manuscript. CG: participated in the design of the study and helped draft the manuscript. All authors read and approved the final manuscript.

\section{Acknowledgements}

Aswini Panigrahi for MS analysis; Ludivine Thomas for MS analysis and providing callus and Robert Ingle for reading the manuscript.

\section{Funding}

This research was funded by King Abdullah University of Science and Technology.

Received: 7 January 2016 Accepted: 3 May 2016 Published online: 11 May 2016

\section{References}

1. Meier S, Gehring C. Emerging roles in plant biotechnology for the second messenger cGMP - guanosine 3', 5'-cyclic monophosphate. Afr J Biotechnol. 2006:5(19):1687-92.

2. Neill SJ, Desikan R, Clarke A, Hurst RD, Hancock JT. Hydrogen peroxide and nitric oxide as signalling molecules in plants. J Exp Bot. 2002;53(372):1237-47.

3. Sanders D, Pelloux J, Brownlee C, Harper JF. Calcium at the crossroads of signaling. Plant Cell. 2002;14(Suppl):S401-17.

4. Newton RP, Roef LUC, Witters E, Van Onckelen H. Tansley Review No. 106. New Phytol. 1999;143(3):427-55.

5. Francis $\mathrm{SH}$, Corbin JD. Cyclic nucleotide-dependent protein kinases: intracellular receptors for CAMP and cGMP action. Crit Rev Clin Lab Sci. 1999;36(4):275-328.

6. Craven KB, Zagotta WN. CNG and HCN channels: two peas, one pod. Annu Rev Physiol. 2006;68:375-401.

7. Bridges D, Fraser ME, Moorhead GB. Cyclic nucleotide binding proteins in the Arabidopsis thaliana and Oryza sativa genomes. BMC bioinform. 2005;6:6.

8. Newton RP, Kingston EE, Evans DE, Younis LM, Brown EG. Occurrence of guanosine 3', 5'-cyclic monophosphate (Cyclic GMP) and associated enzyme systems in Phaseolus vulgaris. Phytochemistry. 1984;23(7):1367-72.

9. Bowler C, Neuhaus G, Yamagata H, Chua NH. Cyclic GMP and calcium mediate phytochrome phototransduction. Cell. 1994;77(1):73-81.

10. Dubovskaya LV, Bakakina YS, Kolesneva EV, Sodel DL, Mcainsh MR, Hetherington AM, et al. CGMP-dependent ABA-induced stomatal closure in the ABA-insensitive Arabidopsis mutant abi1-1. New Phytol. 2011;191(1):57-69.

11. Pharmawati M, Maryani MM, Nikolakopoulos T, Gehring CA, Irving HR. Cyclic GMP modulates stomatal opening induced by natriuretic peptides and immunoreactive analogues. Plant Physiol Biochem. 2001;39(5):385-94.

12. Hu X, Neill SJ, Tang Z, Cai W. Nitric Oxide Mediates Gravitropic Bending in Soybean Roots. Plant Physiol. 2005;137(2):663-70.

13. Penson SP, Schuurink RC, Fath A, Gubler F, Jacobsen JV, Jones RL. CGMP Is Required for Gibberellic Acid-Induced Gene Expression in Barley Aleurone. Plant Cell. 1996:8(12):2325-33.

14. Pasqualini S, Meier S, Gehring C, Madeo L, Fornaciari M, Romano B, et al Ozone and nitric oxide induce cGMP-dependent and -independent transcription of defence genes in tobacco. New Phytol. 2009;181(4):860-70.

15. Pfeiffer S, Janistyn B, Jessner G, Pichorner H, Ebermann R. Gaseous nitric oxide stimulates guanosine-3', 5'-cyclic monophosphate (cGMP) formation in spruce needles. Phytochemistry. 1994;36(2):259-62.

16. Durner J, Wendehenne D, Klessig DF. Defense gene induction in tobacco by nitric oxide, cyclic GMP, and cyclic ADP-ribose. Proc Natl Acad Sci U S A. 1998:95(17):10328-33.

17. Donaldson L, Ludidi N, Knight MR, Gehring C, Denby K. Salt and osmotic stress cause rapid increases in Arabidopsis thaliana cGMP levels. FEBS Lett. 2004;569(1-3):317-20.

18. Meier S, Madeo L, Ederli L, Donaldson L, Pasqualini S, Gehring C. Deciphering CGMP signatures and cGMP-dependent pathways in plant defence. Plant Signal Behav. 2009;4(4):307-9.

19. Ludidi N, Gehring C. Identification of a novel protein with guanylyl cyclase activity in Arabidopsis thaliana. J Biol Chem. 2003;278(8):6490-4.

20. Meier S, Seoighe C, Kwezi L, Irving H, Gehring C. Plant nucleotide cyclases: an increasingly complex and growing family. Plant Signal Behav. 2007;2(6):536-9.

21. Gehring C. Adenyl cyclases and CAMP in plant signaling - past and present. Cell Commun Signal. 2010;8:15.
22. Kwezi L, Meier S, Mungur L, Ruzvidzo O, Irving H, Gehring C. The Arabidopsis thaliana brassinosteroid receptor (AtBRI1) contains a domain that functions as a guanylyl cyclase in vitro. PLoS One. 2007;2(5):e449.

23. Meier S, Ruzvidzo O, Morse M, Donaldson L, Kwezi L, Gehring C. The Arabidopsis wall associated kinase-like 10 gene encodes a functional guanylyl cyclase and is co-expressed with pathogen defense related genes. PLoS One. 2010;5(1):e8904.

24. Kwezi L, Ruzvidzo O, Wheeler Jl, Govender K, lacuone S, Thompson PE, et al. The phytosulfokine (PSK) receptor is capable of guanylate cyclase activity and enabling cyclic GMP-dependent signaling in plants. J Biol Chem. 2011; 286(25):22580-8.

25. Qi Z, Verma R, Gehring C, Yamaguchi Y, Zhao Y, Ryan CA, et al. Ca2+ signaling by plant Arabidopsis thaliana Pep peptides depends on AtPepR1, a receptor with guanylyl cyclase activity, and cGMP-activated Ca2+ channels. Proc Natl Acad Sci U S A. 2010;107(49):21193-8.

26. Mulaudzi T, Ludidi N, Ruzvidzo O, Morse M, Hendricks N, Iwuoha E, et al. Identification of a novel Arabidopsis thaliana nitric oxide-binding molecule with guanylate cyclase activity in vitro. FEBS Lett. 2011;585(17):2693-7.

27. Dubovskaya LV, Molchan OV, Volotovsky ID. Cyclic GMP-Binding Activity in Avena sativa Seedlings. Russ J Plant Physiol. 2002;49(2):216-20.

28. Szmidt-Jaworska A, Jaworski K, Tretyn A, Kopcewicz J. Biochemical evidence for a cGMP-regulated protein kinase in Pharbitis nil. Phytochemistry. 2003;63(6):635-42.

29. Talke IN, Blaudez D, Maathuis FJ, Sanders D. CNGCs: prime targets of plant cyclic nucleotide signalling? Trends Plant Sci. 2003;8(6):286-93.

30. Hoshi T. Regulation of voltage dependence of the KAT1 channel by intracellular factors. J Gen Physiol. 1995;105(3):309-28.

31. Lemtiri-Chlieh F, Berkowitz GA. Cyclic adenosine monophosphate regulates calcium channels in the plasma membrane of Arabidopsis leaf guard and mesophyll cells. J Biol Chem. 2004;279(34):35306-12.

32. Hall BP, Shakeel SN, Amir M, UI Haq N, Qu X, Schaller GE. Histidine kinase activity of the ethylene receptor ETR1 facilitates the ethylene response in Arabidopsis. Plant Physiol. 2012;159(2):682-95.

33. Leng Q, Mercier RW, Yao W, Berkowitz GA. Cloning and first functional characterization of a plant cyclic nucleotide-gated cation channel. Plant Physiol. 1999;121(3):753-61.

34. Leng Q, Mercier RW, Hua B-G, Fromm H, Berkowitz GA. Electrophysiological Analysis of Cloned Cyclic Nucleotide-Gated Ion Channels. Plant Physiol. 2002:128(2):400-10.

35. Hua B-G, Mercier RW, Leng Q, Plants BGA, Do I. Differently. A New Basis for Potassium/Sodium Selectivity in the Pore of an Ion Channel. Plant Physiol. 2003;132(3):1353-61.

36. Ali R, Ma W, Lemtiri-Chlieh F, Tsaltas D, Leng Q, von Bodman S, et al. Death Don't Have No Mercy and Neither Does Calcium: Arabidopsis CYCLIC NUCLEOTIDE GATED CHANNEL2 and Innate Immunity. Plant Cell. 2007;19(3):1081-95.

37. Gao F, Han X, Wu J, Zheng S, Shang Z, Sun D, et al. A heat-activated calcium-permeable channel - Arabidopsis cyclic nucleotide-gated ion channel 6 - is involved in heat shock responses. Plant J. 2012;70(6):1056-69.

38. Wang Y-F, Munemasa S, Nishimura N, Ren H-M, Robert N, Han M, et al. Identification of Cyclic GMP-Activated Nonselective Ca2 + -Permeable Cation Channels and Associated CNGC5 and CNGC6 Genes in Arabidopsis Guard Cells. Plant Physiol. 2013;163(2):578-90.

39. Balagué C, Lin B, Alcon C, Flottes G, Malmström S, Köhler C, et al. HLM1, an Essential Signaling Component in the Hypersensitive Response, Is a Member of the Cyclic Nucleotide-Gated Channel Ion Channel Family. Plant Cell. 2003;15(2):365-79

40. Clough SJ, Fengler KA, Yu I-C, Lippok B, Smith RK, Bent AF. The Arabidopsis dnd1 "defense, no death" gene encodes a mutated cyclic nucleotide-gated ion channel. Proc Natl Acad Sci. 2000;97(16):9323-8.

41. Yoshioka K, Moeder W, Kang H-G, Kachroo P, Masmoudi K, Berkowitz G, et al. The Chimeric Arabidopsis CYCLIC NUCLEOTIDE-GATED ION CHANNEL11/12 Activates Multiple Pathogen Resistance Responses. Plant Cell. 2006;18(3):747-63.

42. Moeder W, Urquhart W, Ung H, Yoshioka K. The Role of Cyclic NucleotideGated Ion Channels in Plant Immunity. Molecular Plant. 2011;4(3):442-52.

43. Ma W, Smigel A, Walker RK, Moeder W, Yoshioka K, Berkowitz GA. Leaf Senescence Signaling: The Ca (2+)-Conducting Arabidopsis Cyclic Nucleotide Gated Channel2 Acts through Nitric Oxide to Repress Senescence Programming. Plant Physiol. 2010;154(2):733-43.

44. Chin K, Defalco TA, Moeder W, Yoshioka K. The Arabidopsis Cyclic Nucleotide-Gated lon Channels AtCNGC2 and AtCNGC4 Work in the Same Signaling Pathway to Regulate Pathogen Defense and Floral Transition. Plant Physiol. 2013;163(2):611-24. 
45. Fortuna A, Lee J, Ung H, Chin K, Moeder W, Yoshioka K. Crossroads of stress responses, development and flowering regulation-the multiple roles of Cyclic Nucleotide Gated lon Channel 2. Plant Signal Behav. 2015;10(3):e989758.

46. Gobert A, Park G, Amtmann A, Sanders D, Maathuis FJM. Arabidopsis thaliana Cyclic Nucleotide Gated Channel 3 forms a non-selective ion transporter involved in germination and cation transport. J Exp Bot. 2006: 57(4):791-800.

47. Guo K-M, Babourina O, Christopher DA, Borsics T, Rengel Z. The cyclic nucleotide-gated channel, AtCNGC10, influences salt tolerance in Arabidopsis. Physiol Plant. 2008;134(3):499-507.

48. Jin Y, Jing W, Zhang Q, Zhang W. Cyclic nucleotide gated channel 10 negatively regulates salt tolerance by mediating $\mathrm{Na}+$ transport in Arabidopsis. J Plant Res. 2014;128(1):211-20.

49. Sunkar R, Kaplan B, Bouché N, Arazi T, Dolev D, Talke IN, et al. Expression of a truncated tobacco NtCBP4 channel in transgenic plants and disruption of the homologous Arabidopsis CNGC1 gene confer Pb2+ tolerance. Plant J. 2000;24(4):533-42

50. Finka A, Cuendet AFH, Maathuis FJM, Saidi Y, Goloubinoff P. Plasma Membrane Cyclic Nucleotide Gated Calcium Channels Control Land Plant Thermal Sensing and Acquired Thermotolerance. Plant Cell. 2012;24(8):3333-48.

51. Borsics T, Webb D, Andeme-Ondzighi C, Staehelin LA, Christopher DA. The cyclic nucleotide-gated calmodulin-binding channel AtCNGC10 localizes to the plasma membrane and influences numerous growth responses and starch accumulation in Arabidopsis thaliana. Planta. 2006;225(3):563-73.

52. Ladwig F, Dahlke RI, Stührwohldt N, Hartmann J, Harter K, Sauter M. Phytosulfokine Regulates Growth in Arabidopsis through a Response Module at the Plasma Membrane That Includes CYCLIC NUCLEOTIDE-GATED CHANNEL17, $\mathrm{H}+-$ ATPase, and BAK1. The Plant Cell. 2015;27(6):1718-29.

53. Shih H-W, DePew CL, Miller ND, Monshausen GB. The Cyclic NucleotideGated Channel CNGC14 Regulates Root Gravitropism in Arabidopsis thaliana. Current Biology. 2015;25(23):3119-25.

54. Frietsch S, Wang Y-F, Sladek C, Poulsen LR, Romanowsky SM, Schroeder II, et al. A cyclic nucleotide-gated channel is essential for polarized tip growth of pollen. Proc Natl Acad Sci USA. 2007;104(36):14531-6.

55. Gao Q-F, Gu L-L, Wang H-Q, Fei C-F, Fang X, Hussain J, et al. Cyclic nucleotide-gated channel 18 is an essential Ca2+ channel in pollen tube tips for pollen tube guidance to ovules in Arabidopsis. Proc Natl Acad Sci. 2016;113(11):3096-101.

56. Tunc-Ozdemir M, Tang C, Ishka MR, Brown E, Groves NR, Myers $C$, et al. A Cyclic Nucleotide-Gated Channel (CNGC16) in Pollen Is Critical for Stress Tolerance in Pollen Reproductive Development. Plant Physiol. 2013;161(2):1010-20.

57. Tunc-Ozdemir M, Rato C, Brown E, Rogers S, Mooneyham A, Frietsch S, et al. Cyclic Nucleotide Gated Channels 7 and 8 Are Essential for Male Reproductive Fertility. PLoS One. 2013;8(2):e55277.

58. Maathuis FJ. CGMP modulates gene transcription and cation transport in Arabidopsis roots. Plant J. 2006:45(5):700-11.

59. Bastian R, Dawe A, Meier S, Ludidi N, Bajic VB, Gehring C. Gibberellic acid and cGMP-dependent transcriptional regulation in Arabidopsis thaliana. Plant Signal Behav. 2010;5(3):224-32.

60. Isner JC, Nuhse T, Maathuis FJ. The cyclic nucleotide cGMP is involved in plant hormone signalling and alters phosphorylation of Arabidopsis thaliana root proteins. J Exp Bot. 2012;63(8):3199-205.

61. Scholten A, Poh MK, van Veen TA, van Breukelen B, Vos MA, Heck AJ. Analysis of the CGMP/CAMP interactome using a chemical proteomics approach in mammalian heart tissue validates sphingosine kinase type 1interacting protein as a genuine and highly abundant AKAP. J Proteome Res. 2006;5(6):1435-47.

62. Luo Y, Blex C, Baessler O, Glinski M, Dreger M, Sefkow M, et al. The CAMP capture compound mass spectrometry as a novel tool for targeting CAMPbinding proteins: from protein kinase A to potassium/sodium hyperpolarization-activated cyclic nucleotide-gated channels. Mol Cell Proteomics. 2009;8(12):2843-56.

63. Donaldson L, Meier S. An affinity pull-down approach to identify the plant cyclic nucleotide interactome. Methods Mol Biol. 2013;1016:155-73.

64. Tamura K, Peterson D, Peterson N, Stecher G, Nei M, Kumar S. MEGA5: molecular evolutionary genetics analysis using maximum likelihood, evolutionary distance, and maximum parsimony methods. Mol Biol Evol. 2011;28(10):2731-9.

65. Toufighi K, Brady SM, Austin R, Ly E, Provart NJ. The Botany Array Resource: eNortherns, Expression Angling, and promoter analyses. Plant J. 2005;43(1):153-63.
66. Zimmermann P, Hirsch-Hoffmann M, Hennig L, Gruissem W. GENEVESTIGATOR. Arabidopsis microarray database and analysis toolbox. Plant Physiol. 2004;136(1):2621-32.

67. Edgar R, Domrachev M, Lash AE. Gene Expression Omnibus: NCBI gene expression and hybridization array data repository. Nucleic Acids Res. 2002;30(1):207-10.

68. Scheible WR, Morcuende R, Czechowski T, Fritz C, Osuna D, Palacios-Rojas N, et al. Genome-wide reprogramming of primary and secondary metabolism, protein synthesis, cellular growth processes, and the regulatory infrastructure of Arabidopsis in response to nitrogen. Plant Physiol. 2004;136(1):2483-99.

69. Saeed Al, Sharov V, White J, Li J, Liang W, Bhagabati N, et al. TM4: a free, open-source system for microarray data management and analysis. Biotechniques. 2003;34(2):374-8.

70. Rojas CM, Senthil-Kumar M, Wang K, Ryu CM, Kaundal A, Mysore KS. Glycolate oxidase modulates reactive oxygen species-mediated signal transduction during nonhost resistance in Nicotiana benthamiana and Arabidopsis. Plant Cell. 2012;24(1):336-52.

71. Macheroux P, Massey V, Thiele DJ, Volokita M. Expression of spinach glycolate oxidase in Saccharomyces cerevisiae: purification and characterization. Biochemistry. 1991;30(18):4612-9.

72. Magrane M, Consortium U. UniProt Knowledgebase: a hub of integrated protein data. Database (Oxford). 2011;2011:bar009.

73. Hunter S, Jones P, Mitchell A, Apweiler R, Attwood TK, Bateman A, et al. InterPro in 2011: new developments in the family and domain prediction database. Nucleic Acids Res. 2012;40(Database issue):D306-12.

74. Zoraghi R, Corbin JD, Francis SH. Properties and functions of GAF domains in cyclic nucleotide phosphodiesterases and other proteins. Mol Pharmacol. 2004;65(2):267-78

75. Aravind L, Ponting CP. The GAF domain: an evolutionary link between diverse phototransducing proteins. Trends Biochem Sci. 1997;22(12):458-9.

76. Ho YS, Burden LM, Hurley JH. Structure of the GAF domain, a ubiquitous signaling motif and a new class of cyclic GMP receptor. EMBO J. 2000; 19(20):5288-99.

77. Narikawa R, Fukushima Y, Ishizuka T, Itoh S, Ikeuchi M. A novel photoactive GAF domain of cyanobacteriochrome AnPixJ that shows reversible green/ red photoconversion. J Mol Biol. 2008;380(5):844-55.

78. Narikawa R, Ishizuka T, Muraki N, Shiba T, Kurisu G, Ikeuchi M. Structures of cyanobacteriochromes from phototaxis regulators AnPixJ and TePixJ reveal general and specific photoconversion mechanism. Proc Natl Acad Sci U S A. 2013;110(3):918-23.

79. Lindermayr C, Saalbach G, Durner J. Proteomic identification of Snitrosylated proteins in Arabidopsis. Plant Physiol. 2005;137(3):921-30.

80. Romero-Puertas MC, Campostrini N, Mattè A, Righetti PG, Perazzolli M, Zolla $\mathrm{L}$, et al. Proteomic analysis of S-nitrosylated proteins in Arabidopsis thaliana undergoing hypersensitive response. Proteomics. 2008;8(7):1459-69.

81. Lozano-Juste J, Colom-Moreno R, Leon J. In vivo protein tyrosine nitration in Arabidopsis thaliana. J Exp Bot. 2011:62(10):3501-17.

82. Cecconi D, Orzetti S, Vandelle E, Rinalducci S, Zolla L, Delledonne M. Protein nitration during defense response in Arabidopsis thaliana. Electrophoresis. 2009;30(14):2460-8.

83. Wang Y-Q, Feechan A, Yun B-W, Shafiei R, Hofmann A, Taylor P, et al. SNitrosylation of AtSABP3 Antagonizes the Expression of Plant Immunity. J Biol Chem. 2009:284(4):2131-7.

84. Raines CA. The Calvin cycle revisited. Photosynth Res. 2003;75(1):1-10.

85. Foyer $\mathrm{CH}$, Bloom AJ, Queval G, Noctor G. Photorespiratory metabolism: genes, mutants, energetics, and redox signaling. Annu Rev Plant Biol. 2009;60:455-84.

86. Jebanathirajah JA, Coleman JR. Association of carbonic anhydrase with a Calvin cycle enzyme complex in Nicotiana tabacum. Planta. 1998;204(2):177-82.

87. Meier S, Gehring C. A guide to the integrated application of on-line data mining tools for the inference of gene functions at the systems level. Biotechnol J. 2008;3(11):1375-87.

88. Meier S, Bastian R, Donaldson L, Murray S, Bajic V, Gehring C. Co-expression and promoter content analyses assign a role in biotic and abiotic stress responses to plant natriuretic peptides. BMC Plant Biol. 2008;8:24.

89. Lamb C, Dixon RA. The oxidative burst in plant disease resistance. Annual Review of Plant Physiology and Plant Molecular Biology. 1997;48(1):251-75.

90. Scholten A, van Veen TA, Vos MA, Heck AJ. Diversity of CAMP-dependent protein kinase isoforms and their anchoring proteins in mouse ventricular tissue. J Proteome Res. 2007;6(5):1705-17.

91. Pelligrino DA, Wang Q. Cyclic nucleotide crosstalk and the regulation of cerebral vasodilation. Prog Neurobiol. 1998;56(1):1-18. 
92. Dubovskaya LV, Volotovsky ID. Affinity chromatography isolation and characterization of soluble cGMP binding proteins from Avena sativa $\mathrm{L}$. seedlings. Bulg J Plant Physiol. 2004;30(1-2):14-24.

93. Laukens K, Roef L, Witters E, Slegers H, Van Onckelen H. Cyclic AMP affinity purification and ESI-QTOF MS-MS identification of cytosolic glyceraldehyde 3-phosphate dehydrogenase and two nucleoside diphosphate kinase isoforms from tobacco BY-2 cells. FEBS Lett. 2001;508(1):75-9.

94. Goldberg JM, Bosgraaf L, Van Haastert PJ, Smith JL. Identification of four candidate cGMP targets in Dictyostelium. Proc Natl Acad Sci U S A. 2002;99(10):6749-54.

95. Bosgraaf L, Russcher H, Snippe H, Bader S, Wind J, Van Haastert PJ. Identification and characterization of two unusual CGMP-stimulated phoshodiesterases in dictyostelium. Mol Biol Cell. 2002;13(11):3878-89.

96. Lucas KA, Pitari GM, Kazerounian S, Ruiz-Stewart I, Park J, Schulz S, et al. Guanylyl cyclases and signaling by cyclic GMP. Pharmacol Rev. 2000;52(3):375-414.

97. Kuo W-N, Kreahling J, Shanbhag V, Shanbhag P, Mewar M. Protein nitration. Mol Cell Biochem. 2000;214(1):121-9.

98. Aggarwal S, Gross CM, Rafikov R, Kumar S, Fineman JR, Ludewig B, et al. Nitration Of Tyrosine 247 Inhibits Protein Kinase G-1a Activity By Attenuating Cyclic Guanosine Monophosphate Binding. Journal of Biological Chemistry. 2014;289(11):7948-61.

99. Murray $\mathrm{Cl}$. New concepts in cardiovascular regulation by post-translational cysteine modification. Baltimore, MD: Johns Hopkins University; 2012.

100. Allocco DJ, Kohane IS, Butte AJ. Quantifying the relationship between coexpression, co-regulation and gene function. BMC bioinform. 2004;5:18.

101. Lee HK, Hsu AK, Sajdak J, Qin J, Pavlidis P. Coexpression analysis of human genes across many microarray data sets. Genome Res. 2004;14(6):1085-94.

102. Ortega-Galisteo AP, Rodriguez-Serrano M, Pazmino DM, Gupta DK, Sandalio LM, Romero-Puertas MC. S-Nitrosylated proteins in pea (Pisum sativum L.) leaf peroxisomes: changes under abiotic stress. J Exp Bot. 2012;63(5):2089-103.

103. Clarke A, Desikan R, Hurst RD, Hancock JT, Neill SJ. NO way back: nitric oxide and programmed cell death in Arabidopsis thaliana suspension cultures. Plant J. 2000;24(5):667-77.

104. Neill SJ, Barros R, Bright J, Desikan R, Hancock J, Harrison J, et al. Nitric oxide, stomatal closure, and abiotic stress. J Exp Bot. 2008;59(2):165-76.

105. Joudoi T, Shichiri Y, Kamizono N, Akaike T, Sawa T, Yoshitake J, et al. Nitrated cyclic GMP modulates guard cell signaling in Arabidopsis. Plant Cell. 2013;25(2):558-71.

106. Hu H, Boisson-Dernier A, Israelsson-Nordstrom M, Bohmer M, Xue S, Ries A, et al. Carbonic anhydrases are upstream regulators of $\mathrm{CO} 2$-controlled stomatal movements in guard cells. Nat Cell Biol. 2010;12(1):87-93. sup pp 1-18.

107. Xue S, Hu H, Ries A, Merilo E, Kollist H, Schroeder Jl. Central functions of bicarbonate in S-type anion channel activation and OST1 protein kinase in CO2 signal transduction in guard cell. EMBO J. 2011;30(8):1645-58.

108. Moreno Jl, Martin R, Castresana C. Arabidopsis SHMT1, a serine hydroxymethyltransferase that functions in the photorespiratory pathway influences resistance to biotic and abiotic stress. Plant J. 2005;41(3):451-63.

109. Turek I, Gehring C. The plant natriuretic peptide receptor is a guanylyl cyclase and enables CGMP-dependent signaling. Plant Molecular Biology. 2016:1-12.

110. Trapet $P$, Kulik A, Lamotte $O$, Jeandroz $S$, Bourque $S$, Nicolas-Francès $V$, et al. NO signaling in plant immunity: A tale of messengers. Phytochemistry. 2015;112:72-9.

111. Li J, Jia H. Hydrogen peroxide is involved in CGMP modulating the lateral root development of Arabidopsis thaliana. Plant Signal Behav. 2013;8(8):e25052.

112. Li J, Wang $X$, Zhang $Y$, Jia H, Bi Y. cGMP regulates hydrogen peroxide accumulation in calcium-dependent salt resistance pathway in Arabidopsis thaliana roots. Planta. 2011;234(4):709-22.

113. Yun B-W, Feechan A, Yin M, Saidi NBB, Le Bihan T, Yu M, et al. Snitrosylation of $\mathrm{NADPH}$ oxidase regulates cell death in plant immunity. Nature. 2011;478(7368):264-8.

114. Yang H, Mu J, Chen L, Feng J, Hu J, Li L, et al. S-Nitrosylation Positively Regulates Ascorbate Peroxidase Activity during Plant Stress Responses. Plant Physiol. 2015;167(4):1604-15.

\section{Submit your next manuscript to BioMed Central and we will help you at every step:}

- We accept pre-submission inquiries

- Our selector tool helps you to find the most relevant journal

- We provide round the clock customer support

- Convenient online submission

- Thorough peer review

- Inclusion in PubMed and all major indexing services

- Maximum visibility for your research

Submit your manuscript at www.biomedcentral.com/submit 